\title{
"Undocumented Convention Refugee in Canada:" the Implications of $\&$ Rationale behind Canada's Identity Document Requirement from Convention Refugees within its Borders
}

$$
\text { by }
$$

\section{Rahma Abdulkadir}

\author{
A thesis submitted to \\ the Faculty Graduate Studies and Research \\ in partial fulfillment of \\ the requirements for the degree of \\ Master of Arts \\ in Canadian Studies \\ Carleton University \\ Ottawa, Ontario \\ March 30, 2006 \\ (C) 2006 Rahma Abdulkadir
}




$\begin{array}{ll}\begin{array}{l}\text { Library and } \\ \text { Archives Canada }\end{array} & \begin{array}{l}\text { Bibliothèque et } \\ \text { Archives Canada }\end{array} \\ \begin{array}{l}\text { Published Heritage } \\ \text { Branch }\end{array} & \begin{array}{l}\text { Direction du } \\ \text { Patrimoine de l'édition }\end{array} \\ \begin{array}{l}\text { 395 Wellington Street } \\ \text { Ottawa ON K1A ON4 } \\ \text { Canada }\end{array} & \begin{array}{l}\text { 395, rue Wellington } \\ \text { Ottawa ON K1A ON4 } \\ \text { Canada }\end{array}\end{array}$

Your file Votre référence ISBN: 978-0-494-16416-7 Our file Notre référence ISBN: 978-0-494-16416-7

NOTICE:

The author has granted a nonexclusive license allowing Library and Archives Canada to reproduce, publish, archive, preserve, conserve, communicate to the public by telecommunication or on the Internet, loan, distribute and sell theses worldwide, for commercial or noncommercial purposes, in microform, paper, electronic and/or any other formats.

The author retains copyright ownership and moral rights in this thesis. Neither the thesis nor substantial extracts from it may be printed or otherwise reproduced without the author's permission.
AVIS:

L'auteur a accordé une licence non exclusive permettant à la Bibliothèque et Archives Canada de reproduire, publier, archiver, sauvegarder, conserver, transmettre au public par télécommunication ou par l'Internet, prêter, distribuer et vendre des thèses partout dans le monde, à des fins commerciales ou autres, sur support microforme, papier, électronique et/ou autres formats.

L'auteur conserve la propriété du droit d'auteur et des droits moraux qui protège cette thèse. $\mathrm{Ni}$ la thèse ni des extraits substantiels de celle-ci ne doivent être imprimés ou autrement reproduits sans son autorisation.
In compliance with the Canadian

Privacy Act some supporting forms may have been removed from this thesis.

While these forms may be included in the document page count, their removal does not represent any loss of content from the thesis.
Conformément à la loi canadienne sur la protection de la vie privée, quelques formulaires secondaires ont été enlevés de cette thèse.

Bien que ces formulaires aient inclus dans la pagination, il n'y aura aucun contenu manquant. 
$\underline{\text { Abstract }} \quad 3$

$\begin{array}{ll}\text { Acknowledgements } & 6\end{array}$

Introduction \& Methodology: $\quad 7$

$\begin{array}{ll}\text { Chapter } 1 & 17\end{array}$

Dynamics of International Migration:

the Case of Unwanted Refugee Movement from "Third World" Countries to the

"First World" - Migration of Somali Refugees to Canada.

Chapter 2

Racism \& Racialization in Canada's Immigration and Refugee Policy:

from Confederation to the Twenty First Century

Chapter 3

Canada \& Refugees: an Outline of the Humanitarian Component of Canada's

Immigration Act as Administered both within and outside Canadian Borders

Chapter 4

The Canadian Government's Rationale behind the Identity Document Requirement

Chapter 5

Somali-Canadian Community's Immigration Experiences (1993-2000):

Some of the Challenges \& Impacts of the Identity Document Requirement

Chapter 6

Resistance: the Struggle towards Substantive Equality

The Charter Challenge:

Conclusion

Bibliography

Appendixes:

Appendix A: Letter of Information and/or Phone Contact Script

Appendix B: Informed Consent Form

Appendix C: Interview Guide

Appendix D: List of Interviewees 


\section{Abstract:}

During the 1990s, the Canadian Government amended Canada's Immigration Act to introduce stricter measures in order to curtail 'uncontrolled or unwanted' refugee migration into the country. ${ }^{1}$ More specifically, the government introduced the infamous identity-document requirement for Convention refugees. The identity document requirement consisted of: (1) subsection 46.04(8) of Canada's Immigration Act, which came into effect in 1993 and (2) the "Undocumented Convention Refugee in Canada Class" immigration program guidelines that were introduced in January 1997. These changes, among other things, reduced the benefits of citizenship i.e. these changes had severe adverse impacts on "undocumented Convention refugees," and the vast majority of these refugees were from Somalia. For example, from 1993 to 1997 Canada's federal Immigration Department denied permanent residence status to thousands of undocumented recognized Convention refugees because they were not able to provide "satisfactory" identity documents as required by subsection 46.04(8) of the Immigration Act. In 1997 this was further complicated by the government's introduction of the "Undocumented Convention Refugee in Canada Class" program guidelines, which put undocumented recognized Convention refugees in a five-year "legal limbo" before they could apply for permanent residence status in Canada.

This thesis evaluates the Canadian Government's rationale behind the identity document requirement while taking into account the environment in which it was introduced. This thesis is also concerned with the major consequences of these changes in this legislation; the implications for the rights of undocumented Somali Convention refugees and protected people in Canada

1 Sherene Razack "Simple Logic: Race, the Identity Document Rule, and the Story of a Nation Besieged and Betrayed" Journal of Law and Social Policy (Vol. 15 2000) 183pp 
between 1993 and 2000 and the Somali refugee community's response to and activism against this legislation.

Thus this thesis asks the following questions: (1) What was the Canadian Government's rationale behind these changes? (2)Did Canada's identity-document requirement single out Somali Convention refugees? If so why were these refugees the main target group of this legislation? (3)Specifically, were there adverse impacts on Somali Convention refugees, i.e. disadvantages not faced by those refugees from countries where "satisfactory identity documentation" was readily available? (4)How did the Somali community respond to this legislation? In answering these questions, this thesis suggests the Government of Canada imposed this identity document requirement on Convention refugees within its borders on the grounds of race and presented via economic and social welfare discourse. In other words, this thesis argues that while there may have been other considerable factors behind the 1990's shift in Canadian refugee policy, racism appears to the most significant factor at the heart of these restrictive immigration measures. The research for this thesis was qualitative in nature and it involved data collection through interviews and analyzing these data; as well as literature review that consisted of analysis of public documents (such as news paper articles, journal articles, webbased literature, texts, and government and community agency publications) in order to provide a comprehensive review of existing literature on exclusion and marginalization of refugees/asylum seekers in Canada. 


\section{Dedication}

To my father, Sh. Abdulkarim Sh. Abdulkadir Sh. Kassim, without whose unconditional love and support I would not be who I am today and to my mother, Asha Sh. Aden, who taught me to be true to myself. 
Acknowledgments:

First and foremost, I would like to thank my husband, Dr. Chetan Dave, without his unlimited love, encouragement and support I would not have been able to complete this project.

Secondly, I would like to acknowledge the significant contributions of my thesis supervisor, Professor Daiva Stasiulis. Her role in the development of my thesis can never be understated. Indeed this thesis has benefited significantly in every respect from her expertise, advice and kind heart. In addition, I take sole responsibility for the shortcomings of this thesis.

Last, but certainly not the least, I would like to thank all of the participants/interviewees for their contributions, who took time out of their busy schedules to sit and share their knowledge with me. 


\section{Introduction \& Methodology:}

During the last few decades, an ongoing debate has emerged about the distinction between Canada's formal and substantive citizenship rights. Human rights advocates argue that citizenship must have both formal and substantive dimensions, in which legal definition and social process act together. ${ }^{2}$ In other words, although the formal conceptualization of citizenship is very much a relevant framework for today's globalized world, it is no longer the only adequate lens from which to view citizenship. It is imperative to recognize the problems that this narrow notion of citizenship, focusing purely on formal citizenship, creates. The reality of today's new world order demands that formal and substantive citizenship be considered equally important. ${ }^{3}$ Advocates of this new and more elaborate definition of citizenship contend that there is a serious disengagement between the ideal political model and its application in Western societies such as Canada. For example, in Western nations ethnic minorities face many new problems as a result of inadequate citizenship rights. These immigrants, such as migrant workers and Convention refugees, "...have been excluded from full citizenship and instead encounter an array of citizenship statuses..." yet citizenship work has been "silent on these issues." Thus, the message here is that the global citizenship debate must be approached from the perspective that modern citizenship is not only a legal and political status, but also a constant renegotiation over the quality of individual and group rights. ${ }^{5}$ In other words, citizenship must be defined as both a set of legal and political rights and responsibilities for the citizen and a method for immigrants to

2Yasmeen Abu-Laban "Restructuring an Inclusive Citizenship for New Millennium: Globalization, Migration and Difference" in International Politics (2000) Vol. $37509-511 \mathrm{pp}$

3 Abu-Laban (2000, 509-515pp)

4 ibid $(2000,521-2 \mathrm{pp})$

5 Daiva Stasiulis \& Abigail Bakan Negotiating Citizenship: Migrant Women in Canada and the Global System (2003) 1-11pp 
challenge the exclusion inherent in the nation-state. ${ }^{6}$ In Canada, non-citizens are in dire need of this broadened definition of citizenship, given that lately many non-citizens in this country have had to employ complex court processes to acquire citizenship rights and basic protection under the law. As Chantal Tie contends, it is highly unlikely that Canada's Government would move to protect immigrant and refugee equality rights without involvement of the courts. Hence, minority groups such as immigrants and refugees in Canada have often relied on the courts to fight injustices imposed on them by discriminatory immigration and refugee policies. For instance, in 1993 the Canadian Government introduced legislation that imposed serious restrictions on the rights of thousands of undocumented recognized Convention refugees within its borders. Given that over ninety percent of those impacted were Somali refugees (approximately 13000$) ;^{7}$ this community launched a long constitutional challenge against the Government of Canada that was settled in 2000 . Other groups affected by the identity document requirement included a few hundred Afghan refugees and a small number of Sri-Lankan refugees; ${ }^{8}$ however, detailed discussion of the specifics of the experiences of these groups is beyond the scope of this thesis as the focus of this study is on the Somali refugee community's immigration experiences since the identity document legislation came into effect in 1993.

Thus, this thesis is a study of the underpinnings of Canada's demand for identity document that was imposed on undocumented Somali Convention refugees within its borders, on the basis of which Canada refused to grant permanent residence status to these refugees between 1993 and 1997. The 1997 "Undocumented Convention Refugees in Canada Class" immigration program guidelines, which according to the government was introduced to relieve some of the

6 Stasiulis \& Bakan (2003, 1-20pp)

7 Tie $(2000,202-215 \mathrm{pp})$

8 ibid (202-215pp) 
hardships created by the identity document requirement that was legislated in 1993; however in actuality this only further delayed the landing or issuing of permanent residence status to thousands of undocumented Convention refugees. Thus, one of the two main focal points of this study is on the Canadian Government's rationale behind the identity document requirement, which discriminated against Convention refugees in Canada, the vast majority of whom were from Somalia, by denying them equality rights. This thesis asks why Canada's federal Immigration Department had declared Somali Convention refugees as unlawful members of society, undeserving of equal treatment in comparison to those Convention refugees in possession of "satisfactory identity documents" (i.e. those refugees who come from countries where "satisfactory identity documentation" would be readily available)? The second central goal of this thesis is to highlight the Somali community's resistance and revolt against the identity document requirement.

While there has been much research done on the identity document problem in Canada; most of this research focused on the impacts of Canada's identity document demand and has been non-academic in nature e.g. many community based reports have been written by refugee and human rights activists in the affected communities, ${ }^{9}$ and by some non-governmental organizations that advocate for refugees both nationally and internationally such as the Canadian Council for Refugees and the United Nation's High Commission for Refugees. The few academic works that have been done in this area are also mainly impact oriented. For illustration, Andrew Brouwer's paper summarizes the specific effects that the identity document requirement has had on undocumented Convention refugees and their families both in Canada and in refugee

\footnotetext{
9 For example, Hamdi Mohamed \& Ahmed Hashi "Beyond Settlement: Economic and Occupational Adjustment of the Somalis in the OttawaCarleton Region" in Report of the Task Force on Employment Project for the Somali Community. October, (1998). Also, the UNHCR and the Canadian Council for refugees have several publication on the impact of the identity document on refugees
} 
camps abroad, and briefly looks at what causes refugees to come to Canada without identity papers. ${ }^{10}$ Brouwer argues that Canada's identity document requirement has lead to the "development of [a socio-economic] underclass of over 13,000 Convention refugees in legal limbo" 11 and recommends the immediate removal of systemic barriers that block these refugees from accessing basic citizenship rights.

Another account of the identity document requirement comes from Goodwin-Gill and Kumin whose paper focuses on the significant legal barriers that the impacted undocumented Convention refugees face in Canada because of the identity document requirement. This paper mainly analyzes Canada's demand for identity documents in "light of its obligations to provide identity documents to refugees under Articles 25, 27 and 28 of the 1951 UN Convention Relating to the Status of Refugees"12 Goodwin-Gill and Kumin contend that Canada's demand for identity documents from Convention refugees is in direct contradiction with its obligations under the 1951 UN Convention relating to the Status of Refugees:
"The contracting states shall as far as possible facilitate the assimilation and naturalization of refugees. They shall in particular make every effort to expedite naturalization proceedings and to reduce as far as possible the charges and costs of such proceedings". ${ }^{13}$

Thus, they conclude with an outline of the following specific options that would allow the Canadian state to fulfill its duties towards recognized Convention refugees within its borders while protecting its own interests:

"(1) ...the issuance of Convention Travel Documents upon recognition by the Immigration and Refugee Board, which simultaneously would satisfy the need for a satisfactory identity document... (2)Identity documents could be issued, either by the Immigration and Refugee Board or by Citizenship and Immigration Canada, to recognized refugees. Where issued, such documents

\footnotetext{
10Andrew Brouwer What's In A Name?: Identity Documents and Convention Refugees (Ottawa: Caledon Institute of Social Policy, March 1999.) $20 \mathrm{pp}$.

11 Brouwer $(1999,18-9 \mathrm{pp})$

12 Guy S. Goodwin-Gill and Judith Kumin Refugees in Limbo and Canada's International Obligations (Ottawa: Caledon Institute of Social Policy, September 2000.) $21 \mathrm{pp}$

13 Goodwin-Gill and Kumin (2000, 15-16pp)
} 
would need to be accepted as satisfactory identity documents for landing, and generally for the purposes of Canadian law... (3) Refugees could be landed immediately upon recognition by the Immigration and Refugee Board, by analogy with refugees resettled by Canada from overseas and who are 'landed' immediately upon arrival... (4)At a minimum, if none of the above options is followed, affidavit evidence or statutory declarations as to identity should be accepted in accordance with the normal principles, and without the limiting reservations currently included in operational instructions. Evidence submitted in Personal Information Forms or in proceedings before the Refugee Division of the Immigration and Refugee Board should be given due weight. Evidence considered sufficient to satisfy the Canadian determination process can also be said to meet the requirements of Articles 25 and 27 of the 1951 Convention."14

Yet another account comes from Professor Sherene Razack, who gives an analysis of the Canadian Government's underlying principle for imposing the legislation that denied permanent resident status to thousands of undocumented Convention refugees and concludes that this systemic discrimination against undocumented refugees is underpinned by Canada's racist national narrative that has always been the basis for its centuries old discriminatory practices against non-European migrants. ${ }^{15}$ In other words, Razack argues that the "simple logic" behind the identity documents requirement brings to the forefront this nation's xenophobic attitudes towards refugees from the global south i.e. Somalia. As valuable as Razack's analysis is, this account does not discuss in depth the "agency" of the impacted Somali refugees and these refugees' constitutional challenge against the Canadian Government.

This thesis builds on all of the aforementioned works as well as other works, and aims to provide an in depth examination of Canada's identity document requirement from recognized Convention refugees and protected persons in Canada by exploring the Canadian Government's rationale behind this requirement; and reviewing Canada's political and economic environment at the time this legislation was introduced; as well this thesis looks at some of the major impacts of this requirement on undocumented Somali Convention refugees in Canada. In particular, this thesis uses Professor Razack's core arguments as starting point in reviewing the "racial

14 Goodwin-Gill and Kumin (2000, 15-16pp)

15 Razack $(2000,183-197 \mathrm{pp})$ 
underpinnings" of the identity document requirement. However, in contrast to the abovementioned literature, this thesis focuses only on the impacted Somali refugees and is different as follows: First of all, this thesis provides a brief historical outline of Somali refugee movement to Canada during the late 1980s and early 1990s. Secondly, this study has two main focal points one of which is the analysis of the Canadian Government's reasons for introducing the identity document requirement; further, while this is very similar to the analysis found in some of the previous academic work on this topic, the second focus point is rather unique for it documents the Somali community's agency in its activism and struggle for basic equality and substantive citizenship rights. This is simply due to the fact that most of the literature available on this topic has been written before the 'reversal' or the amendment of the identity document requirement provision in the Canadian Immigration Act in December 2000, which was a direct result of the Somali community's Charter Challenge against the Canadian Government. Lastly, this thesis, unlike the existing literature on the identity document requirement, empirically documents different perspectives on the identity documents requirement by analyzing qualitative data that were collected through interviews that specifically reveal both the state and the impacted communities' (namely the Somali refugees) standpoint. In other words, while this thesis builds on existing literature, it also offers a unique dialogue between the state and the impacted groups' observations on the identity documents requirement through the analysis of these data.

Further, unlike most of the aforementioned works, the research for this thesis was qualitative in nature, and occurred in two stages: (1) Literature Review: this entailed analysis of public documents (such as, academic journal articles, web-based literature, texts, and government or community agency publications) in order to provide a comprehensive review of 
existing literature on Canada's refugee policy in general and the 1990s changes to this policy as well as a historical profile of the Somali community in Canada and the country they come from. (2) Qualitative Data Collection and Analysis: this stage involved analyzing data collected through interviews with Government of Canada officials, immigration and refugee lawyers in Ottawa, Canada, officials from both non-governmental and inter-government organizations as well as service providers from the Ottawa immigrant/refugee serving organizations who are knowledgeable about the phases and scope of the identity document problem in the Somali Community as well as other impacted refugee communities. A semi-structured interview guide was used for the purposes of collecting these data. The questionnaire or the interview guide contained open-ended questions about: the scope of the identity document problem in the Somali Canadian community; why Somali Convention refugees were the main target group for this policy; and what the affected refugee communities did to fight for substantive equality.

Thus, to address these objectives, this thesis explores the following questions: First, why did the Government of Canada make the decision to deny several thousand recognized Convention refugees permanent residence status based of their lack of "satisfactory" identity documents? Second, who was impacted by this legislation and what were the specific impacts i.e. a disadvantage not faced by those from countries where "satisfactory identity documentation" would be readily available, on these refugees? Third, why were Somali Convention refugees the main target of this legislation? Finally, how did the Somali refugee community refuse to accept to this legislation?

The individuals participating in this research study were professionals who are familiar with the identity document legislation and its effects on Somali Convention refugees in Canada. These professionals included Government of Canada officials, immigration and refugee lawyers 
or experts such as university professors, officials from both non-governmental and intergovernment organizations as well as service providers from the Ottawa immigrant/refugee serving organizations.

Participants were recruited in a non-random purposive manner, based on their publicly known work experience with the legislation in question. Initial contacts arise from the secondary datalliterature review portion of the study, but recruitment was also snowball based on references from initial contacts or participants. Once contact with the individual or agency was achieved, the researcher provided the prospective participant with the information contained in the Letter of Information and/or Phone Contact Script (see Appendix A) in order to determine whether or not the agency representative agreed to participate in the study. The researcher ensured that participant consent was documented either through the signing of a completed Informed Consent Form (See Appendix B) or by a verbal expression of understanding, and consent that was recorded, along with the date and time of consent, by the researcher. Once informed consent was provided and documented, the researcher collected information from the participant questionnaires. All interviews took place in Ottawa, Canada between September 2004 and January 2005. A total of eleven interviews were conducted: four 'refugee and immigration lawyers', four community developers (two front line workers and two directors) and three Canadian Government officials were interviewed for this study.

The thesis has been organized as follows: an introduction, which gives general background of this project as well as the methodological tools employed by the researcher; and six chapters the first of which provides a preamble of the dynamics of international migration, with respect to the tensions between 'unwanted' refugee movement from global south and nation-states in the first world - with an emphasis on the arrival of Somali refugees in Canada. 
The second chapter explores both historical and modern forms of racism in Canadian immigration and refugee policy and exposes the "racial underpinnings" of Canada's 1990s identity document requirement. The third chapter provides a brief overview of origins of Canada's refugee determination system and processes used both in land and overseas by Canadian officials, as well it touches on why refugees in general come to Canada on their own instead of coming via Canada's refugee selection program. The fourth chapter focuses on Canada's requirement of identity documents from recognized Convention refugees. More specifically, this chapter looks into the Canadian Government's rationale behind the introduction of this requirement, as well as the political environment in which it was introduced. In analyzing the rationale that was put forth by the Canadian Government for demanding identity documents from Convention refugees, this chapter sheds some light on the fact that Canada made this demand on the grounds of race, though it was presented via discourses of protecting national security, Canada's rights as a sovereign state, and social welfare security. The fifth chapter attempts to chart the specific experiences of the Somali refugee community in Canada (i.e. some of the major challenges \& hardships created by the identity document requirement). The sixth chapter discusses the Somali refugee community's resistance against and responses to the identity document requirement in general and in particular the path some of the members of the community had to take in their pursuit for substantive equality in Canada. In discussing this community's courage in their great effort to fight against the adversity brought on them by this legislation, this thesis hopes to fill a gap in documenting an important part of the Somali community's history in Canada that is unknown to most Canadians. But first it imperative to chart how and why Somali refugees came to Canada. Thus, the next chapter provides a broad analysis of international refugee migration and a brief historical background of the conditions in 
Somalia that brought thousands of Somali refugees to Canada between the late 1980s and early 1990s. 


\section{Chapter 1:}

Dynamics of International Migration: the Case of Unwanted Refugee Movement from "Third World" Countries to the "First World" - Migration of Somali Refugees to Canada.

Migration simply refers to the movement of people from one place to another, and international migration involves the movement of people from one state to another. People have been migrating since the beginning of time, yet migration is as new as latest political events around the world. ${ }^{16}$ The twentieth century was one of great change with respect to the dynamics international migration. Although, the larger component of theoretical work on international migration has dealt with the question of why people migrate, there has been some attention on the dynamics of human population movement, (e.g. refugee mass movement) and the modern international state system. Further, with today's growing economic interdependence or economic globalization, the mobility of populations is taking an increasingly central position in shaping national political and economic policies. For instance, some argue while the state system has certainly been affected by international population movement, the modern nation has reasserted itself; in contrast, others contend that globalization in the form of migration has called into question the legitimacy of the ruling order or the authority of the modern nation-state in a most fundamental way.

As James Hollifield highlights, the twentieth century has been a period of extraordinary migration worldwide, and one in which national societies became internationalized to a higher degree than ever before. As individuals confronting poverty, violent conflicts, and political repression migrate to socially receptive or expanding economies, however, unintentionally, these movements disrupt existing institutions of social control in both sending and receiving countries. Along with shifts in international power relations, and changing worldwide economic structures,

16 Caroline Brettell and James Hollifield Migration Theory eds., (New York: Rout ledge, 2000)1-2pp 
migration has become an integral part of mutually reinforcing phenomena that are transforming the role of national states in determining national policies. ${ }^{17}$ Hollifield particularly discusses the following three themes: (1) "the role of the nation-state in controlling migration... (2) The impact of migration on the institutions of sovereignty... and (3) the relationship between migration and foreign policy on the one hand and security on the other..."18

Hollifield argues that the role of a strong state in actively pursuing such objectives as open borders based on concepts of laissez-faire competition, and encourage the use of immigrant labor to keep their labor markets competitive or adopt policies of restricted immigration that are compatible with policies of managing labor markets is pivotal. ${ }^{19}$ The ability of a state to intervene and shape industrial society, as well as to withdraw or abstain from intervention, is what distinguishes a strong state. The right of a state to control the openness of its borders is implicit in sovereign authority and is transferred to the structure of an economy. A state that cannot or will not control either its borders or the effect of migrations abdicates both its responsibility and its potential as a strong state. Hollifield goes on to explain that the competitive attitudes of economic globalization are dictating changes in citizenship and this could be attributed to the means of integrating immigrant labor i.e. Economic globalization is seen as the culprit here. In sum, Hollifield concludes that the debate surrounding international migration generally focuses on economic migrants as a positive development. Nevertheless, the changes created by porous international borders are successfully redefining the boundaries of sovereign domain, and as a result, the notion of borders - hence both national sovereignty and security are

17 James Hollifield "Politics of International Migration: How can we bring the state back in" in Caroline Brettell and James Hollifield Migration Theory Eds. (New York: Rout ledge, 2000) 137pp 18 Brettell and Hollifield (2000,6pp)

19 Hollifield (2000: 137-140) 
challenged by international migration. ${ }^{20}$ Simply put, this conceptualization suggests that the power of the state to manage its internal policies has been weakened, and international migration flows have in particular contributed to this process of eroding the sovereignty of the nation state. Therefore, concludes Hollifield, the state must reclaim its power and have more prominence in the politics of migration. Among other things, this would require the nation state to have a more active role in managing migration flows in general and refugee migration in particular. Thus, this perspective put forth the notion that refugees or asylum seekers are merely at the mercy of the nation-state rather than rights bearing individuals, and suggests that asylum seeking flows should be managed humanely through programs of integration. ${ }^{21}$ This view is very problematic in many ways: first of all, states do not always "manage humanly" the needs and rights of asylum seekers and recognized Convention refugees within their border. Further, the body of opinion that focuses on the worth of state sovereignty and the need for effective border control often undermines refugees' basic human rights, which in turn chips away at fundamental liberal democratic values such as fairness and equality. Furthermore, the idea that the nation-state has been weakened by migration is rather flawed. For illustration, as Tanya Basok emphasizes "...whereas in some areas the state has indeed experienced decline, in other areas it has retained control and in some, it has reasserted itself with more vigor., ${ }^{, 2}$ In the era of neo-liberalism, the state has become more interventionist in dissuading "unlawful migrants" (e.g. refugees) from reaching or crossing its borders and continues to develop policies that lead to the systematic decomposition of refugee rights and protections. ${ }^{23}$ Thus, Basok calls for a re-examination of the

\footnotetext{
20 Hollifield, (2000: 164-175)

21 ibid (2000:173-176pp)

22 Tanya Basok "Refugee Policy: Globalization, Radical Challenge, or State Control" in Studies in Political Economy Vol. 50 (Summer 1996)

$137-8 \mathrm{pp}$

23 Basok $(1996,133-8 p p)$
} 
"post-Westphalian" argument that the powers of the state are "withering away". For illustration, there has been little concerted effort to incorporate race or racialization of certain groups into theories of international migration. Indeed, the race factor is critical when it comes to unwanted migration (i.e. interstate refugee movement) from the global south to the first world. In part, this is due to the fact that migration theory has traditionally emphasized the causes of international migration over questions of who migrates. It has often failed to adequately address the discriminatory underpinnings of Western governments' exclusionist immigration/refugee policies. ${ }^{24}$ Furthermore, traditional theories fail to convey the circumstances under which refugees become international migrants and sometimes enter into trafficking channels, or some of the conditions that push them to reach the borders of the "first world" on their own. ${ }^{25}$ Basok contends "today, governments retain a significant degree of autonomy in refugee matters...governments may decide to consider some migrants as genuine refugees;" ${ }^{26}$ while viewing others as "bogus refugees" that must be subjected to restrictive immigration measures.

Likewise, Razack contends that, in Canada, the "bogus refugees" argument relies "...on the [imagined] figure of illegal immigrant, the immoral man intent on taking what is not his, a man whose culture and morality is the very opposite of ${ }^{27}$ his host society. Thus, the perpetuation of Canadian narrative in which a "...sovereign nation forced to protect itself from unscrupulous and envious hordes... ${ }^{28}$ of immigrants/refugees at its doorsteps or, as in the case of Somali Convention refugees in Canada in the 1990s, living within its borders; hence, the introduction of seemingly neutral immigration/refugee policies that have discriminatory

\footnotetext{
24 Basok (1996, 139-140pp)

$25(1996,139-141 \mathrm{pp})$

$26(139-143 \mathrm{pp})$

27 Razack $(2000,195 \mathrm{pp})$

28 ibid (2000, 195pp)
} 
underpinnings, which in turn have race-specific results and differential devastating outcomes for certain racialized groups. For example, in Canada's identity documents requirement rule against undocumented refugees, Somalis made up the vast majority of those impacted by Canada's identity document requirement. In sum, the modern nation state has not been weakened by population movement and this is illustrated by the states' undying ability to re-legitimize its authority over its borders e.g. legislating immigration/refugee policies that assist in admission of desired immigrants and restrict unwanted migrants such as refugees. The rest of the chapter maps out the migration of such a group - Somali refugee movement to Canada.

\section{A Map of Somali Refugee Migration to Canada:}

In Western political thought the state is defined as a legitimate political body that possesses definite territory, an active government, and the autonomous recognition of other states. $^{29}$ Also, a legal state must have an adequate representation of its inhabitants in order to care for their interests. As Professor Ali Mazrui states, in this sense, pre-colonial Somalia was not a nation with a central state but rather a nation with anarchy as its system of government. ${ }^{30}$ The common sociological belief is that early Somalis shared a common language (with several dialects) and lineages that can be traced back to a few common forefathers. ${ }^{31}$ Somalis are predominantly Muslim and share a highly decentralized pastoral lifestyle. ${ }^{32}$

Although these characteristics may denote a level of homogeneity among Somalis, it is imperative that one understands the role clanism, the division of Somalis into clans and subclans, plays in shaping the politics landscape. As I. M. Lewis states in his book A Pastoral

\footnotetext{
29 Allen Sens \& Peter Stoett Global Politics: Origins, Currents, Directions Australia; Scarborough, ON: Nelson Thomson Learning, 2002. 34pp 30 Ali Mazrui "From Tyranny to Anarchy" in Mending Rips in the Sky The Red Sea Press, Inc. 1997 5-7pp 31 Mazrui $(1997,5-7 \mathrm{pp})$

32 ibid $(1997,5-7 \mathrm{pp})$
} 
Democracy, "the key to Somali politics lies in kinship."33 However, it is imperative not to confuse tribalism, with clanism; tribalism refers to a permanent territorial unit acting as the basis of social organization, while clanism refers to a much more fluid concept based on lineage and kinship. ${ }^{34}$ Somalis along with their nomadic and egalitarian social practices possessed a form of 'pastoral democracy' characterized by fluid contractual agreements rather than the formal political structures of the modern nation-state. Among other things, this means that prior to the imposition of the European colonial state, Somalia was not a state in the modern definition of the word; it was a commonwealth or an umma, a moral order rooted in blood ties (i.e. patre-lineal descent and marital or hidid affinities) and customary law. ${ }^{35}$ In other words, the traditional precolonial pastoral communities created authority structures for themselves that were more suitable for nomadic living. This commonwealth's uppermost leader, also known as Suldaan or Ugaas, was considered the symbolic head of the clan. However, it is important to note that the leader in most Somali nomadic communities did not have as much power as that of an African chief. ${ }^{36}$ Thus, the Suldaan was simply a political figurehead with little institutional clout. This means these pastoral communities had a decentralized or subtle hierarchical power structure in which every family could make major decisions. ${ }^{37}$ This plurality and dispersion of decision-making is a major characteristic of nomadic existence. Thus, the Somali relationship between clan identities and the state tends to center on reasserting the role of kinship. In other words, clanship has

33 M.I. Lewis A Pastoral Democracy (1961, 1-3pp)

34 Lewis $(1961,1-10 p p)$

35 ibid (1961, 1-10pp)

36 Lewis (1961,1-10pp)

37 ibid (196110-15pp) 
always been and continues to be a versatile ethnic construction as a result of forceful power because of its ostensibly inherent character in the Somali culture. ${ }^{38}$

More recent analysis of clanship's impact on Somali political history argues that it is dangerous to assert clanism as a determining principle of Somali social organization. ${ }^{39}$ For example, Ahmed Samatar contends:

"While this view does not completely dismiss the role of primordial affinities in
the emerging struggle over the state in Somalia, it is an attempt to go beyond
any single determinism and consider the interaction of various factors i.e.
clanism and intra-class competition among them..."

In other words, it is imperative to realize that in combination with clanism, other key factors such as Somalia's forced insertion into the world capitalist economy, the uneven development of peripheral capitalism and the subordination of pastoral relations to an economic and political nexus dominated by the state, have resulted in the recent destruction and defeat of the Somali nation by deterioration into lawless desperation. ${ }^{41}$ In sum, pre-colonial Somalia was an ancient pastoral culture that was to a certain extent the cohesive that characterized it. This pre-colonial commonwealth was incrementally dismantled through colonial rule, and later completely destroyed under the military rule of Mohammed Siyad Bare.

During the nineteenth century Somalia saw political developments that transformed it permanently. During this period, both the rule of inter-regional powers (Egypt, and Ethiopia) and European powers (Britain, France, Italy, and Portugal) subjugated the Somali nation and its people. $^{42}$ These colonial powers had different economic interests in Somalia. For example, by occupying the Somali regions of Zeila and Berbera, Egypt could secure access to the Nile that

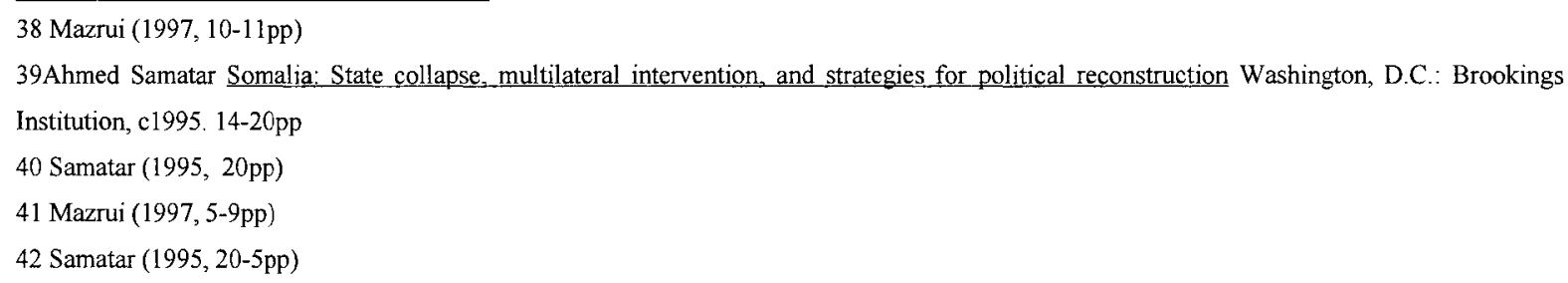


would provide easy access to Ethiopia's Lake Tana, a source of the Nile. ${ }^{43}$ With the assistance of Britain between late 1870s to mid 1880s, Egypt ruled from Zeila and Berbera to the inland centre of religious learning in Harar. ${ }^{44}$ Also, in the early 1890 s the Ethiopian emperor Menelikh laid claim to Somali territory for strategic defense and economic interests. As Samatar explains prior to direct European colonial interests, it was these interests, which corresponded with the Middle East's introduction of trade and commerce that slowly eroded the old ethical orderliness of the Somali commonwealth.

As the importance of the Red Sea intensified for British operations in the East, Aden, located in present-day Yemen, gradually became indispensable to the defense of British India. Thus, Britain sought control of the Somali coastal regions to establish military administrations in specific regions in this country (i.e. North, Northwest and South Somalia). Britain was especially interested in securing this source of livestock products for its naval port of Aden. ${ }^{45}$ Simultaneously, France, competing with Britain, wished to establish a coaling station on the Red Sea coast to strengthen naval relations with their Indochina colonies; therefore, it extended its foothold on the Afar coast partly to counter the influence of British authorities and partly to mark its own colonial territories in the Horn of Africa. ${ }^{46}$ Other European colonial powers such as Italy and Portugal deferred to Britain and laid claim to Somalia territories whenever possible. As a direct result of these European colonial interests, Somalia was officially divided into the five regions during the late 1890s: (1) British Somaliland (present day North Somalia); (2) Italian Somaliland (South Somalia); (3) French Somaliland (present day Djibouti); (4) Ogaden Region

43 Samatar (1995, 20-5pp)

44 ibid (1995, 20-5pp)

$45(1995,30-45 \mathrm{pp})$

$46(30-45 \mathrm{pp})$ 
(Western Somalia continues to be under Ethiopian rule); and (5) Northern Kenya (this part of modern day Kenya). ${ }^{47}$

By the beginning of the twentieth century, Somalia had undergone a plethora of interrelated political processes that eventually caused serious economic and political underdevelopment as well as severe societal consequences for the Somalis in the latter part of the century. Colonial influences slowly shifted the country's economy from a subsistence economy to market pastoralism. This eroded the commonwealth between these pastoral communities and their territories and divided Somalia into five colonial outposts. ${ }^{48}$ Perhaps the most damaging legacy was the imposition of the colonial state, often referred to as an old 'Pastoral Democracy.'

Both North and South Somalia became independent from colonial rule in 1960. Shortly thereafter, North and South Somalia voluntarily united. In less than a decade, this country underwent a series of political reformations, leading to General Mohammed Siyad Bare's 1969 coup. The military seized power, disbanded the National Assembly, and suspended the constitution, making Bare the head of the Supreme Revolutionary Council. ${ }^{49}$ Bare's political support beyond the military came from urban intellectuals and technocrats who wished to diminish the power of clan identification and establish a modern Somali nation-state. As is often the case under military rule, Bare reacted to challenges to his authority with severe reprisals, particularly during the last years of his regime. In short, at best Bare's regime was a combination of neo-Marxism and nationalism, highly common regimes in post-colonial Africa. ${ }^{50}$

As Samatar explains, the state inherited from the colonial governments was supposedly reconstructed to provide "more appropriate governance structures for the people and economic

47 Samatar (1995, 30-50pp)

48 ibid $(1995,30-50 \mathrm{pp})$

49 (1995 30-55pp)

$50(30-55 \mathrm{pp})$ 
systems that enhanced sustainable development in the post-independence period." ${ }^{, 51}$ Unfortunately, these measures were not taken because the de-colonization process was not only "unwilling and opportunistic," but also insufficient to address issues of Africa's effective participation in the post-independence political economy. ${ }^{52}$ This was partly because the European colonial powers had very little interest in adequately transforming the critical domains (e.g., economy, bureaucracy, educational system, etc.) to make them more appropriate for postindependence development. ${ }^{53}$ At independence, Somalia, like other African nations, inherited government and economic systems that were alien and designed for the exploitation of indigenous populations, not for their advancement. In turn, this caused:

"...high levels of poverty and deprivation; marginalization of popular forces; endemic political violence, including destructive clan conflict; bureaucratic and political corruption; suffocation of civil society; unmanageable external debts; economic and political decay; military opportunism; continued economic dependence on the outside economies; and education systems unable to serve the needs of their people." 54

The nation state and societal collapse that took place in Somalia was rooted in the fundamental clash between the pastoral basis of social relations and the organizational requirements of the modern centralized nation-state power. ${ }^{55}$ In the end, Somalia's experience under Bare's regime turned into a highly costly nightmare that still haunts the country even after the fall of the regime.

Rebel forces drove out Bare and his regime in early 1991. This was followed by an endless civil war, the result of which was that basic civil institutions disappeared. Since 1991, Somalia has been a nation without a government, and cleavages of armed clan militiamen fighting over the spoils replaced the country's central security authorities. For over a decade, the

\footnotetext{
51 Samatar $(1995,62 \mathrm{pp})$

52 ibid $(1995,62-9 \mathrm{pp})$

$53(1995,62-9 \mathrm{pp})$

54 ( 62-9pp)

55 (75-89pp)
} 
militiamen engaged in ravaging the land as well as systematically killing and displacing the civilian population. The victimization of women, particularly the displaced, continues to be widespread. Further, in the early 1990's, the international community experienced limited success in its attempts to break the cycle of civil war, human rights' violations, and famine, even though conditions grossly breached international standards of living. ${ }^{56}$ As a result of this inexhaustible civil war, millions of Somalis fled their homes, becoming displaced persons within their own country and unwelcome refugees in neighboring African countries, the Middle East, Europe and North America. In particular, as mentioned above, Somali refugees faced many complex challenges that directly resulted from the amendment of Canadian refugee and immigration policies in the early 1990s. The next chapter explores the connection between Canada's infamous historic reluctance towards migrants, including refugees, from the global south and the 1990s shift in Canadian immigration and refugee policies.

56 Samatar (1995, 75-89pp) 


\section{Chapter 2:}

Racism \& Racialization in Canada's Immigration and Refugee Policy: from Confederation to the Twenty First Century

The refugee problem of the world is not new; however, the last three decades of the twentieth century witnessed the rise of awareness of how this problem affected Western societies such as Canada. ${ }^{57}$ In 1978, the Canadian Parliament passed an official Immigration Act to ensure that Canada's demographic, economic and social needs as well as its international obligations (i.e. refugee resettlement) were fulfilled. ${ }^{58}$ "Canada's total fertility rate has remained below replacement levels" ${ }^{\$ 59}$ since the mid-1970s; therefore the question of an optimal size for the Canadian population and how that population should be distributed in terms of age has repeatedly arisen on the federal government's list of immigration policy priorities. Given Canada's low birth rate and noticeably aging population, demographic principles called for increased numbers of young immigrants who already had or potentially would soon have progeny. Nevertheless, in the 1980s immigration officials' attempts to weigh in the demographic factor to some extent when processing applicants at overseas posts were not really very successful as Canada continues to face the same demographic problems two decades later. ${ }^{60}$ Another key objective of Canada's Immigration Act is directly connected to the Act's Family Class Category. This immigration category attempts meet the goal of bringing together families that want to be reunited - a long-standing cornerstone of Canadian immigration policy. ${ }^{61}$ However, the administration of the family class provisions, including fulfilling the processing requirements, have often come under the criticisms of being time consuming and thus frustrating

57 Anthony Richmond Global Apartheid: Refugees. Racism and the New World Order (Toronto: 1994) 133-6pp 58 Nassir Islam Canada's Immigration Policy: Compassion, Economic Necessity or Lifeboat Ethics" in Katherine A. Graham's edition of How Ottawa Spends 1989-90: The Buck Stops Where? Ottawa: Carleton University Press, 1989), 208-240pp 59 Islam $(2000,225 \mathrm{pp})$ 60 Jakubowski $(1997,280 \mathrm{pp})$ 61Islam $(2000,225-33 \mathrm{pp})$ 
for the sponsors (Canadian citizens and Permanent Residents sponsoring their immediate family members) particularly when the sponsored relatives are in countries where there are no or limited capacity visa offices e.g. Africa and Asia. ${ }^{62}$ While the causes of delay may be numerous, critics have stressed that the number of immigration officials that were available to actuall process applications is at times inadequate to deal promptly with family class applications. ${ }^{63}$

Yet another important objective of Canada's immigration policies involves economic development i.e. the need for immigration program that attract young, well educated professionals to build Canada's workforce and help the country compete in the dominant international capitalist economic system. Two decades later it was obvious that unlike the other immigration objectives (demographic, family reunification and refugee resettlement), economic determinants significantly shaped immigration policy. For example, since 1978, if the conditions were prosperous and employment was high, the "gates" opened wider for immigrants and refugees; when the economy encountered a downturn, the "gates" narrowed for immigrants as the "government reacted with restrictive immigration policy." 64

Nonetheless, as Razack observes, while Canada's economic needs may have been at the center of all its immigration policies, there still continues to be strong "xenophobic tendencies" that are associated with these policies. For instance, the 1990 s refugee policy reforms suggest that the Canadian Government used the economic discourse to "cover up" its averseness to refugees from the global south. ${ }^{65}$ Furthermore, Razack suggests that

"faced with the immovability of the simple logic, and the seeming rationality of the country protecting its borders from the unscrupulous, few critics have suggested that racism [was what enabled] the identity document rule to apply to [Somali ] refugees ... [nevertheless] ...critics of identity document provisions

62 Jakubowski $(1997,25)$

63 Islam $(2000,236-40 \mathrm{pp})$

64 Islam (1989, 208-12pp)

65 Razack $(2000,193-7 \mathrm{pp})$ 
have mainly stayed in the less confrontational realm of " disproportioned impacts and systemic discrimination, concepts that do not produce the defensiveness that a charge of racism does" $" 66$

In other words, Canada's identity document requirement from Convention refugees had serious racial underpinnings. So, is this an accurate assessment of Canada's identity document requirement rule? Here it is very important to point out that Canada, unlike its southern neighbor (the United States), is a country that prides itself in being multiethnic-multicultural mosaic where all ethnicities-cultures come together "freely and equally"; ${ }^{67}$ however, it is also imperative to ask how/why had this new burden on refugees come to be? In answering this question the rest of this chapter attempts to analyze the role of racism or racialization of certain groups in the introduction and application of the identity document provisions issue by reviewing the role of race/racism in Canada's immigration policies in general, and the underlying racial elements of the 1990s Canadian refugee policy shift in particularly.

Some of the earliest development of theories of racism and ethnic relations came out of the United States and Britain within in several disciplines of Social Science e.g. Sociology, and Political Science. ${ }^{68}$ In theorizing racism, modern Sociologists have argued that if racism is built on a subjective labeling of groups on the basis of their phenotypical differences and/or the color of their skin or "inherited cultural uniqueness," given that science has permanently deflated thoughts of fundamental human dissimilarities, then race becomes a constructed or imagined concept that does not have tangible relationship to reality. ${ }^{69}$ Socio-Political theories of racism include Political Economy Theories of Racism, which center on the ideological aspect of racism

66 Razack (2000, 183-197pp)

67 Sherene Razack Razack “.Making Canada White: Law and the Policing of Bodies of Colour in the 1990s", in Canadian Journal of Law and Society 14(1), (Spring 1999)159-184

68 Tracy E. Ore The Social Construction of Difference and Inequality: Race, Class, Gender and Sexuality (2002)

69 Vic Satzewich "Race, Racism and Racialization" in Racism and Social Inequality in Canada (1998) 24-31pp 
rather than its biological or scientific content. ${ }^{70}$ In other words, these theories focus on the processes of racialization instead of race relations to explain how/why in different societies social significance has been connected to phenotypical differences. ${ }^{71}$ So what is the link between racialization and racism? And how does it relate to Canada's immigration/refugee policy? According to Satzewich there is a connection between these two concepts and this link is demonstrated in Canada by such phenomena as

"...democratic racism, [which] refers to a peculiarly Canadian form of racism that reflects an effort to reconcile two fundamentally conflicting sets of values...many Canadians take pride themselves in their commitment to democratic principles such as justice, equality and fairness, but at the same time have negative attitudes about and discriminate against minority groups"72

According to Anthony Richmond

"...the term democratic racism has been used to describe the ambivalence of many people in contemporary societies that simultaneously subscribe to [explicitly] liberal democratic values and implicitly racist attitudes and practices." 73

Thus, racism, in different forms, has been and continues to be a significant aspect of Canada's past and present histories. This chapter evaluates both historical and modern forms of racism in Canadian immigration and refugee policy in order to expose the "racial underpinnings" of Canada's 1990s identity document requirement.

In general, instances of racism in Canadian history include, but are limited to, how Canada's indigenous communities, among other things, were "dispossessed" of their land by an invading European settler society. In terms of immigration policy, at the turn of the twentieth century Canadian authorities had a strong desire to exclude non-European immigrants. ${ }^{74}$ Canadian immigration objectives and their implementation at the turn of the twentieth century reflected this country's aversion to non-European immigrants. This desire reflected a certain

70 Ore (2002)

71 Ore (2002)

72 Satzewich $(1998,24-31 \mathrm{pp})$

73 Anthony Richmond "Refugees and Racism in Canada" in Refuge: Canada's Periodical on Refugees Vol. (19) No. 6 (August 2001) 15pp

74 Razack (1999, 180-184pp) 
antipathy and fear from this white-settler society towards non-whites. Thus, Canadian immigration policies and practices from the time of confederation until the 1960s indicated the xenophobic attitudes of Canadian society at the time. ${ }^{75}$ Furthermore, due to the fact that the federal government's immigration policies were based on race, religion, and ethnic origin, until the 1960s non-white applicants for immigration had serious legal and political disadvantage when they attempted to come to Canada. Some of the groups that were singled out or discriminated against included but were limited to "individuals of African origin, Chinese, Japanese, Jews and South Asians. ${ }^{, 76}$

More specifically, the Canadian Government designed its immigration policies specifically to attract those deemed "acceptable" immigrants (mainly individuals from Northern Europe), to severely restrict the immigration of certain ethnic groups, to extradite immigrants deemed unsuitable for the Canadian community, and to occasionally reject naturalization to certain racial groups. For example, with the discovery of gold in the Fraser River Valley in April 1858 , Chinese prospectors began arriving in Canada in large numbers. ${ }^{77}$ By the early 1860 s the Chinese population in British Columbia grew rapidly. ${ }^{78}$ The result of this was an institutionalized racism against the Chinese in which their citizenship rights as well as opportunities to compete in the market were denied and they were subject to penalizing taxes. ${ }^{79}$ Also, attitudes of white Canadians toward the Chinese were ambivalent. For example, the Chinese were regarded as "racially undesirable" but good for the economy.

75 Laquian. (1998, 10-14, 10-16pp)

76 Chantal Tie Immigrant Selection \& Section 15 of the Charter: A study of the Equality Rights of Applicants for Admission to Canada

(University of Ottawa LLM Thesis: 1995) 3-9pp

77 Knowles (1997, 50-53pp)

78 ibid., (1997, 50-53pp)

79 Laquian (1998, 10-13pp) 
Further, when British Columbia joined Confederation, the province had no independent laws regulating immigration but soon passed "anti-Chinese" immigration laws in an effort to drive the Chinese from the country. ${ }^{80}$ What's more, the province enacted various laws to tax, control and disenfranchise Chinese. For instance, all Chinese were required to register and pay tax, prohibited from working in position of trust and from voting. ${ }^{81}$ Also, British Columbia was not the only province to enact anti-Chinese legislation. In fact, Saskatchewan and Manitoba also had similar laws in place. $^{82}$

Moreover, as soon as the railway was completed and the unemployed Chinese contract laborers failed to go back to China, anti-Chinese public pressure intensified and became focused on ensuring that no more Chinese entered the country. The federal government passed the first Chinese Immigration Act in 1885 with expressed purpose of limiting Chinese immigration. ${ }^{83}$ As outlined by Jakubowski, the most effective restrictive measure introduced by the government was the financial disincentive known as the "head tax" - introduced in the 1885 Chinese Immigration Act. ${ }^{84}$ This meant that every Chinese immigrant had to pay $\$ 50$ to land in Canada. Since the "head tax" only temporarily decreased the number of Chinese immigrants the government kept on increasing the tax $\left(\$ 100\right.$ in 1901 and $\$ 500$ in 1903). ${ }^{85}$ The Chinese continued to be subjected to special restrictive regime until diplomatic pressures from China were directed at Great Britain, who in turn pressured the Canadian Government to disallow the British Columbia anti-Chinese Acts. ${ }^{86}$

\footnotetext{
80 Tie (1995, 3-15pp)

81 Laquian $(1998,14 \mathrm{pp})$

82 ibid. (1998, 14-20pp)

83Knowles (1997, 50-63pp)

84 Knowles (1997, 51 pp)

85 ibid., (1997, 50-53pp)

86 Laquian (1998, 10-13pp)
} 
Similarly, early settlement of people of African origin in Canada lead to the introduction of a series of federal legislations aimed at eliminating or, at the very least, minimizing Black immigration to Canada. For illustration, in 1947 Mackenzie King stated in the House of Commons "Canada is perfectly within her rights in the persons whom we regard as desirable future citizens...it is not a fundamental human right of any alien to enter Canada, [but] a privilege ${ }^{987}$ Further, as Tie explains:

\begin{abstract}
"Black immigrants were screened at the port of entry for compliance with existing health, literacy and financial regulations... When a large group of African-American settlers were admitted following the most rigorous examinations possible, in which all were found to be eligible for entry, there was mounting pressure for direct legislative exclusion...In 1910 the Canadian Pacific Railway, pursuant to an agreement with the government, issued restrictive regulations denying Black settlers the free organized tours of Western Canada and reduced the rail rates available to white American settlers...Later records of the Privy Council for 1911 showed that the government recommended that Black immigration be prohibited...Census figures suggest that the measures taken against Black settlers were successful. Between 1900's and 1950s the Black population of Canada remained constant, indicating a steady reduction in this group as a percentage of the Canadian population...Further, although there are no accurate statistics available on how many settlers from this community were turned away at ports of entry or refused settler certificate, it is often contended that the policy of aggressively discouraging Black settlement and the strict interpretation of existing regulations at the borders were responsible for the static Black population in Canada before the 1950s." ${ }^{88}$
\end{abstract}

Furthermore, in Canada the colour-line of racial disparity between "whites and blacks" was evident in education, government, the workplace, residential housing etc. ${ }^{89}$ This is illustrated by the "enforcement of residential segregation, separation and/or refusal of services to black customers in restaurants, theaters and other facilities"90 long after slavery was "abolished" in Canada. Among other things, this highlights that "white supremacy" has been deeply embedded in Canada's immigration and refugee policy; as well the above brief historical survey of Canada's immigration and refugee policy indicates that, from its initiation, this policy has been fundamentally tied to racial prejudice, particularly towards people of non-European origin.

\footnotetext{
87 Robin Winks The Blacks in Canada: A History McGill-Queen's University Press (Montreal: 1971) 435pp

88 Tie $(1995,3-10 \mathrm{pp})$

89 Tie $(1995,3-15)$

90ibid (1995, 3-20pp)
} 
In contrast to the early twentieth century, the late 1960 s marked a significant shift in Canadian immigration and refugee policy as a result of economic and demographic changes in this country. For example, the traditional source countries, post World War II European countries that were prospering, were no longer providing sufficient numbers of immigrants; further, new labour demands were beginning to emerge in Canada as a result of rapid industrialization and technological development that required workforce with high education and labor skills. ${ }^{91}$ These factors pushed the Canadian Government to radically reform its immigration and refugee policy and abandon the explicitly ethnocentric and racist immigration tactics in favor of a "non-racist one." 92 Furthermore, in contrast to the Canada of the early twentieth century, modern-day Canada prides itself on its "multiculturalism" and pluralism. For example, since the 1980s nonEuropeans make up the majority of immigrants, including refugees. ${ }^{93}$

Nevertheless, despite the 1960s radical reform in Canada's immigration and refugee policy, critics argue that this nation's "nativist and xenophobic" attitudes keep on resurfacing with every new tide of non-European immigrants/refugees. So how can a society that has actively outlawed racism be accused of being "nativist and xenophobic"? In answering this question it is important to consider the concept of racialization, which insinuates that while "biological versions of racism may very well be dead, other forms of racism have emerged in their place." 94 Satzewich is instructive here:

"The study of the causes and consequences of belief in race...constitutes [understanding] the essence of one of the central problems in the contemporary sociology of race and racism: how and why does the race label continue to be reproduced...? The study of these kinds of questions what is ... [referred] to as the racialization problematic ${ }^{95}$... racialization [then] refers to those instances

\footnotetext{
91 Yasmeen Abu-Laban \& Christina Gabriel Selling Diversity: Immigration, Multiculturalism, Employment Equity \& Globalization (2002)

92 Nassir Islam "Economics, Humanitarian or lifeboat Ethics" in How Ottawa Spends (Ottawa: 2000) 210pp

93 Richmond (1994 130-140pp)

94 Vic Satzewich "Race, Racism and Racialization" in Racism and Social Inequality in Canada (1998) 36pp

95 Satezewich $(1998,32 \mathrm{pp})$
} 
where social relations between people have been structured by the signification of human biological characteristics in such a way as to define and construct differentiated social collectivities ${ }^{96}$...there are a whole range of identities, relations and boundaries in Canada and elsewhere that are instances of racialization." 97

In other words, in Canada this is illustrated by the institutionalization of systemic discriminatory practices found in Canada's seemingly neutral immigration and refugee policy and declarations of nation building and national economic development, while deflecting and/or denying racist influences or outcomes. In particular during the 1990s, economic and national security arguments were used to veil the racial underpinnings of Canada refugee policy reforms i.e. the identity document requirement that was imposed on recognized Convention refugees. As Satzewich contends, when it comes to institutional racism in Canada“...there are circumstances where a racist discourse is modified in such a way that the explicitly racist content is eliminated, but the new words carry the original meaning." 98 Furthermore, certain institutional practices that may appear to have "universalistic and non-racist" outlook in supposition, could in actuality have devastating effects for some groups. ${ }^{99}$ Canada's identity document requirement from Convention refugees had serious racial underpinnings in the sense that it was directed against specific minority groups in this country. In analyzing Canada's identity document demand Razack points to the symbolism behind this requirement and suggests that

"... it is in the realm of the symbolic that it becomes difficult to steer clear of the issues of racism ... [this is how] the racial story of the identity documents, our insistence on knowing who refugees are... derives strong support from the liberal notion of sovereign state that has the right to control entry and to maintain a distinction between the rights of those inside and those outside its borders." 100

Hence, the Canadian Government's assertion that undocumented refugee presented both an economic burden and national security threat to this country.

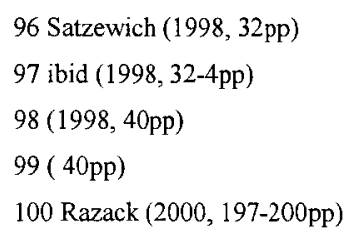


According to Anthony Richmond, this shift in Canadian refugee policy was part of a trend across Western nations during the 1980s and early 1990s. Richmond also points out that Canada has the predicament of having contradictory economic and "humanitarian" obligations in its immigration policy; ${ }^{101}$ However, Richmond highlights that during the $1990 \mathrm{~s}$, immigration and refugee policies in this country were the center of "much racist discourse and practice."102 As mentioned above, Canada's ostensibly neutral immigration and refugee policies appear to be inclusive of all groups but, in fact, have systemic barriers built into them; one must view these policies as racist because they lead to a situation in which specific groups are deprived of basic rights; hence, "such policies are systemic forms of discrimination." ${ }^{103}$ For illustration, on the one hand Canada denied permanent residence status to several thousand Somali and Afghan recognized Convention refugees within its borders because they lacked identity documents and kept most of these refugees in immigration limbo for almost a decade; on the other hand, in 1999, Canada "accepted 5,000 refugees from Kosovo and exempted them from the identity document requirement provisions" 104 that were applied to refugees from Somalia and Afghanistan.

In addition, almost all of Canada's refugee selection criteria such as literacy tests, health regulation, medical examination, quotas etc. could be classified as policies that have differential effects on particular nationalities. ${ }^{105}$ For example, Somali refugees in refugee camps in Africa often do not get selected by Canada as a large number of them do not meet Canada's requirements or criteria for refugee selection. ${ }^{106}$ This demonstrates that racism still prevails in

\footnotetext{
101 Richmond (1994, 136-9pp)

102 ibid (1994, 155pp)

103 (1994, 155-6pp)

104 Razack (2000, 183-197pp)

105Richmond (1994, 155-6pp)

106 Interview \# 3
} 
Canada's attempts to contain refugee movement to Canada. ${ }^{107}$ The Canadian Government backed by the recommendations of the Economic Council of Canada, views economic migrants as a benefit to the Canadian economy in the long run and aims to substantially increase the number of economic immigrants. On the other hand, refugees in general are believed to be adding to "social costs of immigration, which are largely borne by Provincial and Municipal Governments."108 This is evident in the shift from the language of "burden sharing" to a new "security" discourse. A central argument in this security discourse is the notion that refugees increase demands on scarce resources, which in turn exacerbates this perceived threat that refugees seem to elicit in their host societies by their sheer presence; and therefore, are portrayed as a threat to the host country's national security. The language of security veils the fact that the threat perception can often be attributed to a policy of containment or to the absence of burden sharing. This leads to the wearing away of fundamental values that protect refugees and asylum seekers as Canada feels justified in creating an economic underclass of refugees in immigration limbo within Canadian borders; or closing its borders to individuals fleeing from persecution or returning refugees to war torn countries all under the banner of upholding state sovereignty and protecting Canada against various security threats. For example, as per Canada's new Immigration and Refugee Protection Act (IRPA), which came into effect in June 2002, Canadian visa offices abroad no longer accept direct asylum applications from refugees as they did in the past. Under IRPA immigration officers are required to only accept asylum applications forwarded by the United Nations High Commission for Refugees. This puts severe restrictions on refugees applying for asylum as the numbers of accepted cases, even with referral of the UNHCR, get fewer and fewer year after year. As Judith Kumin points out this is due to the fact that 
"resettlement ... is ... available each year to less than 1 per cent of the world's refugees.",109 Such policies have resulted from such discourses.

Thus, in questioning the existence of a "closed door" refugee policy in Canada today, it is important to inquire about the "open door" refugee policy that Canada adopted during the post-World War II era. ${ }^{110}$ According to Whitaker, “...the golden era of refugee acceptance not only coincided with the Cold War; it was a product of the cold war." 111 This statement implies that the open-door refugee policy was a mere "side effect" of this ideological war between the "West and East" or the "First and Second" worlds, and that the ideology argument overrides the “...alleged racist instincts of Western governments and societies." 112 However, others have argued that today's refugee policies are different from those of the post war epoch not only because of ideology, but also for the reason that the displaced people of World War II were not racially perceived as a threat and had a lot more in common with their hosts. ${ }^{113}$ In the context of euro-centrism, the refugees of the post-World War II and during the cold eras were of similar cultures, backgrounds and religions to those of the societal majority. Thus, while "humanitarianism" certainly contributed to the welcoming of those refugees; the fact that these refugees were not perceived as racially different from their hosts, certainly eased tensions between the two groups. ${ }^{114}$ However, in today's globalized world, thousands of new refugees come every year from places like Africa, Asia and the Middle East, ${ }^{115}$ and the arrival of the Southeast Asian refugees in the late 1970s as well as the influx of East African refugees between

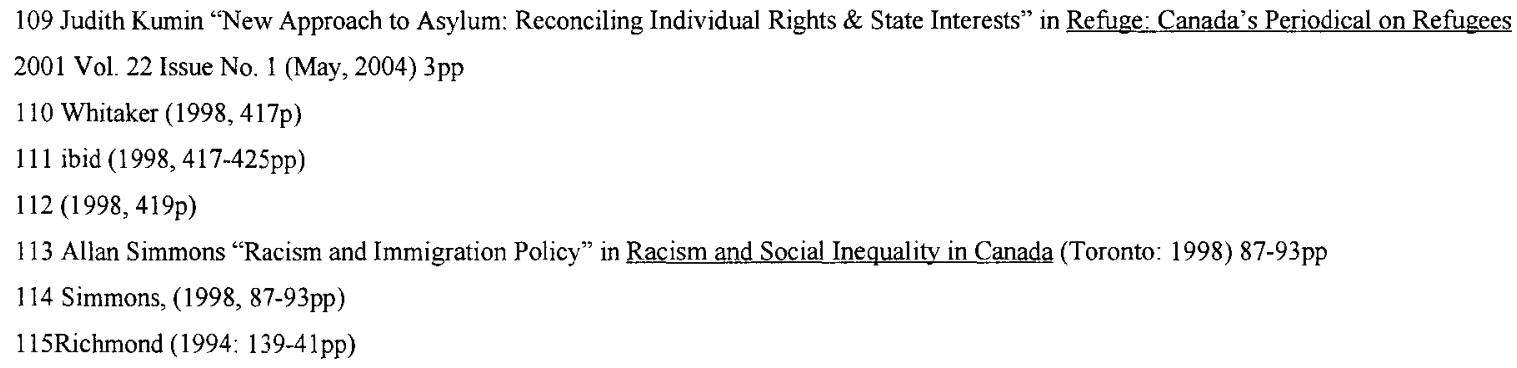


late 1980 s and early 1990 s has triggered negative responses in the sense that backlashes against refugees or permanent asylum-seekers in Canada seem to increase with each new wave of refugees. ${ }^{116}$

For instance, refugee rights activists in Canada argue that the restrictionism and discrimination in the Canadian refugee and immigration policies are inter-linked with intolerance of refugees/immigrants, xenophobia and racism towards these groups. ${ }^{117}$ Indeed, in Canada, where open expression of racist ideas is generally not tolerated, hostility towards newcomers serves as an outlet for the expression of underlying racist sentiments, and this is especially true in times of economic or political difficulty, when those with less power, including newcomers, are easy scapegoats for the shortcomings of society. ${ }^{118}$ Moreover, anti-refugee/immigrant prejudices foster hostility and violence against newcomers, and result in official policies that infringe on the rights of 'non-citizens'. ${ }^{119}$ Although the overall immigration policy framework is explicitly 'nonracist', studies have shown that there are in fact many indicators of 'neo-racism' underlying the process. ${ }^{120}$ In Canada, the immigration policy framework, which includes refugee policy, continues to reflect elements of racism that are incessantly perpetuated by an unwillingness to critically interrogate immigration policy from an 'anti-racist' perspective. ${ }^{121}$ Finally, as Allan Simmons contends, perhaps the biggest obstacle to creating "anti-racist" immigration and refugee policies in this country is that immigration discourse tends to almost completely exclude the social or cultural histories of non-Western-European immigrant groups who have settled in Canada.

\footnotetext{
116Canadian Council for Refugees http://www.web.net/\%7Eccr/id.htm 117 Laquian (1998 20-4pp) 118Jakubowski (1997, 20-21pp) 119Laquian (1998, 24-9pp) 120 Simmons $(1998,94-9 \mathrm{pp})$ 121 Razack $(2000,183-97)$
} 
In short, the above discussion highlights some key arguments in Canadian immigration discourse in general and the debate surrounding the rudiments of the 1990s shift in Canada's refugee policy in particular. For instance, Canada's support of and emphasis on multilateral international refugee assistance, especially when it comes to African and Asian refugees, is reflective of its unshakable belief in the view that refugee resettlement in a third country (e.g. traditional immigration countries such as Canada and the United States) must not be encouraged until other "durable" solutions such as repatriation to country of origin have proven unworkable. Even when resettlement is the only option, refugees must satisfy Canada's special criteria in order to be selected for resettling in Canada. For example, refugees in refugee camps in Africa (e.g. Somalis in Kenya's refugee camps) often wait years before they are selected for resettlement by countries like Canada. In addition, Somali undocumented Convention refugees in Canada were denied the right to sponsor immediate family members (i.e. spouse and dependent children) as only permanent residents of Canada and Canadian citizens can sponsor family members under the Canadian Immigration Act. This double edged sword had cut into these refugees' ability to reunite with their families and, in some cases, brought about the permanent separation of families.

Moreover, when refugee claimants show up at Canada's points of entry they are often viewed, both by the Canadian Government and society, as forces interfering with Canada's capacity to select the "right kind" of refugees and as such pronounced to be potential security risk and law breakers that Canada must deal with under strict procedures. Thus, economic determinants are not the only factors behind the shift in refugee policy. ${ }^{122}$ Systemic racism has also reshaped immigration policy in general. In particular, this decline in Canada's generosity

122 Richmond (1994) 
towards refugees has it roots in the historic racist Canadian national narrative that continues to define Canada as "white settler society". As Whitaker states:

"...the luxury of the golden age of refugee policy in Canada and other Western countries was mainly reserved for Europeans...Canada's closed door refugee policy centers on third world asylum seekers who are politicized and criminalized because their host society suspects them to be fraudulent despite the fact that they are qualified recognized Convention refugees under the 1951 Geneva Convention by the Canadian Immigration Board."123

In sum, as mentioned above, while economic factors may have had significant influence over Canadian refugee policy during the 1990s; the race/racism factor has always played and continues to play a greater role in these policies both at the federal and provincial levels. This is further elaborated on in the next chapter, which focuses on the origins of the Canada's refugee determination system - the humanitarian component in the Canadian Immigration Act.

123 Whitaker $(1998,417 \mathrm{p})$ 


\section{Chapter 3:}

Canada \& Refugees: an Outline of the Humanitarian Component of Canada's Immigration Act as Administered both within and outside Canadian Borders

The humanitarian component of Canada's immigration policies i.e. refugee resettlement, like other categories of the Immigration Act has a rather interesting history. First of all it is imperative to point out that while it is not perfect Canada's refugee assistance programs including its refugee determination system is one of the best in the world. Thus this chapter aims to review Canada's refugee policy that guide the processing of inland refugee claimants and the application process that is used overseas by Canadian Visa Officers to select refugees in refugee camps. In doing so this chapter sheds some light on why some refugees come to Canadian ports of entry to claim refugee status instead of coming through the government's refugee selection procedures.

As mentioned above, one of the main objectives of Canada's 1978 Immigration Act was to ensure Canada's international humanitarian obligations (i.e. refugee resettlement) were fulfilled. Nonetheless, many Canadian commentators noted that of all the elements of the immigration policy, the humanitarian issues (i.e. refugee policy) were the most controversial and highly criticized. ${ }^{124}$ Historically, any enthusiasm on the part of Canada to take on significant responsibility and, in turn, visibly improve its dominion and international image, came about incrementally. It was not until the late 1940's that Canada decided to pursue programs that contributed to international development and supported the ideology behind the United Nations' concepts of cooperation, peace, and global stability. ${ }^{125}$ More specifically, a review of Canada's early interests in international humanitarian and social issues points to its past preference for more authority over uncontrolled human migration particularly where refugees were

$124 \operatorname{Islam}(1989,215 \mathrm{pp})$

125 David Matas \& Ilana Simon Closing the Doors: the Failure of Refugee Protection Summer hill Press (Toronto: 1989) 87-103pp) 
concerned. $^{126}$ Furthermore, the focus of Canada's early contributions to international humanitarian assistance for refugees often were towards the support of other countries and agencies, such as towards the United Nations High Commission for Refugees (UNHCR) to provide international relief to refugees and displaced peoples. Thus, Canada has always encouraged the importance of using inter-governmental organizations such as the UNHCR and International Organization for Migration to search for resolution for the world's refugee problem. As well, Canada has displayed a strong belief in the threat of large numbers of refugees and displaced peoples. In other words, this is a country that has tended to view these individuals as not only having an impact on countries of first asylum, but also international security, peace and stability, and has continuously advocated for solid resolutions to the world's refugee problem for both humanitarian and political reasons. ${ }^{127}$ Although Canada's dealings with refugee issues date back to the early 1920 's; ${ }^{128}$ Canada's role as a key player in the international refugee regime began in the late 1940's when it enthusiastically partook in resettlement assistance of World War II refugees. ${ }^{129}$ Even then, many argue, Canada was enthusiastic in participating in the international refugee resettlement after World War II not only for humanitarian reasons i.e. Canada had economic interests behind this humanitarian act, as it was interested in utilizing these refugees as a means of building its post-war labour force.

Half a century later, Canada is one of the few countries that offer resettlement for refugees who have no other durable solutions available to them. Like other signatories of the 1951 Convention, Canada's definition of refugee or asylum-seeker comes from the United

126 Matas \& Simon $(1989,248-55 \mathrm{pp})$

127 ibid $(1989,248-55 \mathrm{pp})$

128 Basok $(1996,137-8 \mathrm{pp})$

129 ibid (1996, 138pp) 
Nations' 1951 Geneva Convention Relating to the Status of Refugees and its 1967 Protocol, which state that refugees are:

\begin{abstract}
"... persons who by reason of a well founded fear of persecution based on race, nationality, political opinion or membership in a particular social group, are outside the country of nationality are unable to or, by reason of that fear, unwilling to be protected by that country; or not having a country of nationality, are outside the country of former habitual residence are unable to or, by reason of that fear, unwilling to return to that country."130
\end{abstract}

The 1951 Geneva Convention Relating to the Status of Refugees was a direct result of a new international order attempt, which at the time was symbolized by the United Nations, to assist displaced people (e.g. the Jewish refugees from Nazi Germany and eastern Europeans displaced by Soviet occupation of their lands, who had difficulty finding safe haven else where). ${ }^{131}$ Further, although the initial convention dealt only with the post-World War II refugees, later this was modified to include other individuals. However, it is important to note that the actual definition of the Convention did not change. It is this Convention that is used by signatory countries such as Canada to determine whether a claimant is or is not a refugee. In addition, the United Nations Handbook on Refugee Status dictates that it is the international duty of signatories to provide reasonable means of establishing refugee status; however, a standard structure binding all signatories to such duties has not yet been established, in turn, each country has its own refugee-determination system. ${ }^{132}$ For instance, Canada did not have a refugeedetermination system prior to the proclamation of the 1978 Immigration Act. In fact, previous to 1978 whenever national or international forces pushed the Canadian Government to admit groups of refugees or displaced peoples, the Cabinet was required to pass an order-in-council, which meant that the government examined each refugee emergency separately, as no general

$130 \mathrm{http} / /$ www.cic.gc.ca/english/refugees/asylum-1.html

131 Matas \& Simon $(1989,87-93 \mathrm{pp})$

132 ibid $(1989,87 \mathrm{pp})$ 
guidelines or determination system were in place at the time. ${ }^{133}$ This ad hoc process to refugee determination stayed in operation until the 1978 Immigration Act came into effect, introducing Canada's first refugee-determination system. ${ }^{134}$

Generally, similar principles apply to both overseas and inland claimants; however, there are some significant differences in the processing of these claimants. According to Canada's refugee-determination system, within Canadian borders a refugee claimant has the right to make a refugee claim; then, the Canadian Government makes the decision whether he/she needs refugee protection. Such a decision is made using the following categories:(1) Convention Refugees: a convention refugee is an individual who has a well-founded fear of persecution in his/her home country; or an individual who fears persecution based on one's race, religion, nationality, membership in a particular social group or political opinion; ${ }^{135}$ (2) Persons in need of protection: persons in need of protection refers to an individual who faces danger of torture if he/she is returned to his/her home country; or an individual who is personally at risk of being killed or of being subject to cruel and unusual treatment or punishment throughout his/her home country. ${ }^{136}$ Further, an individual must show that he/she fits at least one of these categories to be granted protection in Canada.

In terms of the actual legal process, inland refugee claimants can make a refugee claim at any Canadian port of entry (including at the airport if one arrived on an international flight) or inside Canada (Citizenship and Immigration Canada inland refugee processing offices). The same basic process applies whether an individual claims at a port of entry or at an office inside Canada. After he/she makes a claim, the first step is to decide whether he/she is eligible to have

\footnotetext{
133Matas \& Simon $(1989,87-90 \mathrm{pp})$

134 ibid $(1989,87-90 \mathrm{pp})$

135 Citizenship and Immigration Canada http:/www.cic.gc.ca/english/refugees/asylum-1.html

136 http://www.cic.gc.ca/english/refugees/asylum-1.html
} 
his/her claim referred to Canada's Immigration and Refugee Board (IRB) for a hearing; this decision is made by Citizenship and Immigration Canada. The Immigration and Refugee Board (IRB) is an independent tribunal that is separate from Citizenship and Immigration Canada. ${ }^{137}$

\begin{abstract}
"The IRB hears and makes decisions on claims for refugee protection and on some immigration matters, and the division that hears refugee claims is called the Refugee Protection Division... The Immigration and Refugee Board sends the claimant a notice by mail telling him/her when and where to appear for their hearing...After the hearing IRB makes a decision regarding the validity of the claim...All claimants are sent by the IRB a document called a Notice of Decision and if your claim is accepted, one is granted convention refugee or protected person status in Canada."
\end{abstract}

As a Convention refugee, an individual can apply and obtain permanent residence status as soon as the IRB has granted him/her Convention refugee status. Further, prior to the 1993 identity-document requirement, Convention refugees were able to apply for permanent residence status within two years of their arrival in Canada. This allowed Convention refugees to settle permanently and showed that Canada recognized that in the best interest of refugees, their dependants, and all Canadians refugees had to be integrated and become participating members of Canadian society as quickly as possible. ${ }^{139}$ Nevertheless, this changed in 1993 when the Canadian Government amended the Immigration Act and introduced the identity document requirement from recognized Convention refugees in Canada before they were allowed to apply for permanent residence status. So why did the Canadian Government, which sponsors and provides documents to undocumented refugees in camps all over the world, decide to deny basic citizenship rights to thousands of undocumented recognized Convention refugees within its borders?

According to respondents, who are Canadian Government officials, this very selective refugee resettlement program has been put in place by the Canadian Government as an attempt to

137http://www.cic.gc.ca/english/refugees/asylum-2.html

$138 \mathrm{http} / /$ www.cic.gc.ca/english/refugees/asylum-2.html

139 Canadian Council for Refugees website http://www.web.net/\%7Eccr/doceng.htm\#resettle 
balance the tensions between Canada's international humanitarian duty to refugees and its capacity to absorb limited number of refugees. In other words, it is important to keep in mind that Canada is a small country and, hence, it can not possibly take in all of the world's displaced people. ${ }^{140}$ Therefore, the design of this program reflects the delicate balance between Canada accepting its international obligation to help refugees and Canada's actual capacity. "Besides, most of the legitimate refugees wait in refugee camps for their turn to be processed abroad,"141 while inland claimants come to Canada jumping ahead of all those who comply with Canadian immigration requirements, which meant that Canada had to amend its refugee policy in the 1990 in order to protect the integrity of its refugee determination system against bogus refugees. ${ }^{142}$ This brings up the question that if in fact Canada has a generous system in place to select and assist refugees from abroad for resettlement in Canada why do some refugees "choose" to not go through the "proper channels" - (i.e. let the Canadian Government select them to resettle in Canada)?

One refugee lawyer stated that Canada's refugee selection processes are not generous and tend to put Canada's preferences before the needs of the refugees. For example, given the processes that the Canadian Government has put in place for sponsoring refugees, many of the inland claimants would most likely not have been able to come to this country if they had waited for the government's permission. ${ }^{143}$ A refugee case worker, frontline worker at an immigrant and refugee serving agency in Ottawa, further explains that one major reason is that Canada selects refugees using similar criteria as it uses for immigrant selection, and as a result of Canada's narrow preferences, Canada compels refugees to show up at its points of entry. For illustration:

140 Interview \# 1

141 Interview \# 5

142 Interview \# 5

143 Interview \# 2 
"the waiting period is too long (sometimes ten to fifteen years before one is selected for resettlement in Canada) to wait for any government to select them; or they do not qualify under the "successful establishment" criterion because of a language barrier as most of the refugees are not fluent in either of Canada's official languages or they might get rejected because Canadian Visa Officers would decide that they would not be able to adapt to Canada or Canadian ways of doing things - this does happen to some refugees who then try to come here on their own, and some of these do succeed in their endeavor; Furthermore, it is ridiculous to expect people fleeing for their lives to have all of these qualifications." "144

Canada's refugee selection criteria are as follows:

"The requirements that refugees have to meet are as follows: (1) Eligibility: the person must be found to be at risk by meeting one of the following definitions: a Convention refugee... (2) Country of asylum class (outside the country of origin and "seriously and personally affected by civil war, armed conflict or massive violation of human rights"), or Source country class (meeting one of the two preceding categories, but inside the country of origin and that country is designated by Regulation)... (3) Admissibility: the person must not have committed a crime, represent a security risk, or pose a danger to public health and safety... (4) Successful establishment: the person must show a capacity to become successfully established in Canada...and (5) No prospect of another durable solution: the person must have no reasonable prospect of voluntary repatriation, local integration or resettlement in another country...,"145

A refugee lawyer points to some of the preconceived prejudices that inland claimants have to face when they arrive at Canadian points of entry i.e. both the Canadian Government and the general population often view them as interfering with Canada's selection of the "right kind" of refugees. Thus, they perceive these refugees as potential lawbreakers that Canada should restrict; this misconception only makes the refugee problem worse. ${ }^{146}$ Another respondent, a refugee lawyer, contends that refugees sometimes "jump the queue" because other than outside of resettlement in a third country, there are no "real durable solutions" to the refugee problems that exist today, especially in Africa where refugees must live in camps for many, many years or perhaps for the rest of their lives if they do not get selected by countries like Canada. ${ }^{147}$ Also, it is important to look into what is considered a "durable solution," and look into who has the

144 Interview \# 6

$145 \mathrm{Ihttp} / /$ www. web.net/\%7Eccr/doceng.htm\#resettle

146 Interview \#4

147 Interview \# 2 
power to make such a decision for these individuals whose lives are at stake. ${ }^{148}$ There is much attention given to the concept of durable solutions to the world's refugee problem. As Matas outlines, there are three such solutions that are internationally recognized:

"(1)Voluntary repatriation to country of origin, which is the preferred solution by all involved... This usually happens either when the cause of the refugee flow has been clearly removed (e.g. the end of a civil war) or when the circumstances in the refugees' region of origin in a country may have the potential to pave the way successful repatriation (e.g. a region of the country of origin is stable enough to assist the refugees from that region to return even though the whole country has not necessarily stabilized)...(2) Local settlement in the country of first asylum, which involves the integration of refugees into the country of first asylum, (e.g. Somali refugees' countries' of first asylum are Djibouti, Ethiopia and Kenya depending on which part of Somalia the refugees fled); (3) Third country resettlement is for those refugees who have no option of repatriating to their country of origin or integrating into the country of their first asylum." 149

Also, it imperative to point out that the identity-document requirement does not apply to those individuals selected by Canada i.e. undocumented Convention refugees in refugee camps, as required under the 1951 Geneva Convention Relating to the Status of Refugees and its 1967 Protocol, are processed by the UNHCR beforehand and are provided with proper UNHCR refugee identity documents. ${ }^{150}$ The Canadian Government then gives Canadian travel documents to the refugees who are selected and sponsored by the government. In general, Canada also grants permanent residence status to those refugees who are sponsored, either by the government or private based sponsors, before they reach Canada. In contrast, inland claimants without "satisfactory" identity documents are often treated like criminals and are accused of being "bogus" refugees. Thus, it is important to ask the question: given that having identity document papers would essentially make the in land refugee claim process much more easier for both the claimants and the Canadian, why do these refugees have no identity documents?

148 Interview \# 9

149 Matas $(1989,87-9 \mathrm{pp})$

150 Interview \# 9 
There are as many reasons why refugees lack identity documents as there are refugees in the world. However, most refugees, particularly those who come from war-torn countries such as Somalia, often leave identity documents behind in their desperate attempts to escape persecution. Also it is often the case that war torn countries do not have functioning governments from which the refugees can obtain identity documents. ${ }^{151}$ Others who are fleeing oppressive regimes are able to get "satisfactory" identity documents, but resort to using false identity documents to "hide their identity from their persecutors." 152 Furthermore, some refugees, such as Somali refugees, do not come from cultures that rely on paper identity documentation as much as Canadian society does. For example, Canada systematically documents births, marriages and deaths; however in Somalia, paper-based proof is of little importance, and in turn, they do not necessarily officially document such events on paper, e.g. Somalis have an oral culture in which identity and relationships are documented through oral testimony of family members or community elders. ${ }^{153}$ Unlike Canada, Somalia has always been, and continues to be, an oral society. For instance, news by word of mouth still has an enormous significance for Somali refugees in different parts of the world. Further, "the Somali language was only written down in the early 1970s." ${ }^{154}$ Prior to the 1970s Somalis used foreign languages, namely Arabic, English and Italian, for written communication. However, in the early 1970s the then new Siyad Bare regime "decided to adopt the Roman script for the language." 155 This was for several strategic reasons one of which was financial i.e. "typewriters in government offices would not need to be

151 Interview \# 6

152 Interview \# 3

153 Interview \# 3

154 Anthony Olden "Somali Refugees in London: Oral Culture in a Western Information Environment" in Libri 1999, vol. 49, pp. $212-214$. Centre for Information Management, Thames Valley University, London, UK. Printed in Germany 155 Olden $(1999,216 \mathrm{pp})$ 
replaced," $" 156$ and the fact that colonial rule left behind a civil service machinery that was operating in either Italian or English given that most of the work force was educated in one of these languages. Nevertheless, the introduction of written Somali did not really have much impact on the strong centuries old oral culture that continues to be preferred by Somalis everywhere. As Anthony Olden found in his research on Somali refugees in the UK

$$
\begin{aligned}
& \text { "...word-of mouth is the most successful way to communicate with Somalis: if } \\
& \text { you want people to pay attention to leaflets containing useful information, you } \\
& \text { need to hand these out to them in person, not distribute them through the } \\
& \text { mail.".157 }
\end{aligned}
$$

More purposely, as Andrew Brouwer points out, this is indicative of the fact that prior to the 1991 civil war in Somalia a large portion of the population was still living as nomads, i.e. "Somalis did not register their births, marriages or divorces ...this cultural reality is not unique to Somalia, but is shared by many other countries, especially in Africa." 158 These are some of the reasons that lead to refugees entering through Canadian ports without identity documents. These facts were also recognized by the Canadian Government; yet the government introduced the identity document requirement legislation and demanded identity document papers from these refugees. The next chapter examines the Canadian Government's rationale for introducing the identity-document legislation. 


\section{Chapter 4:}

\section{The Canadian Government's Reasoning}

In general, refugees or asylum-seekers have come to symbolize conflict at the core of the modern nation state. "The conflict between individual rights and state sovereignty, and the friction between private rights and public obligation is particularly evident when refugee law is primarily focused on the protection of the nation-state instead of refugees." ${ }^{159}$ Excessive focus on the rights of the state is rooted in the claim that a sovereign state has "absolute" authority over its national territories. The term sovereignty has a long history beginning with Aristotle and continuing through Hobbes and the French and American revolutions to arrive at yet another major transformation. ${ }^{160}$ Although it was originally synonymous with the sovereignty of the tyrant, the will of the people became contained in the concept of the nation-state i.e. popular sovereignty, defined as an element of democracy that periodically allows the public to exert its will through general elections. ${ }^{161}$ Further, the sovereignty of the modern state was constituted in mutually exclusive territories and concentration of sovereignty in the nation state. In other words, the rule in the modern world flows from the "absolute" sovereignty of the state over its national territories. Moreover, this territorial exclusivity was indeed a very difficult task to achieve, and only after centuries of wars, hardship, and broken treaties did it come to nationalize territories along mutually exclusive lines and secure the distinct concentration of power and today's sovereign state. ${ }^{162}$

More recent analyses of the modern international nation-state system and its authority over the individual nation-state, reveals that the twentieth century's populations movements, in

\footnotetext{
159 Jacqueline Bhabha "Embodied Rights: Gender Persecution, State Sovereignty, and Refugees" 160 Devtak \& Higgot $(1999,484-5 \mathrm{pp})$

161 ibid $(1999,484-5 \mathrm{pp})$

$162(1999,484-9 \mathrm{pp})$
} 
particularly refugee migration, may have unintentionally weakened the state's ability to have control over its borders. ${ }^{163}$ Thus, human migration, legal or illegal, has permanently impacted the role of nation-states in determining national policies. ${ }^{164}$ In other words, during the last four decades of the twentieth century, the dynamics of economic globalization carried the capacity and incrementally undid the form of sovereignty embedded in today's modern state system. Thus sovereignty of the nation-state has become a less important feature in the international system, and "the nation-state as an entity has been under considerable challenge."165

Others have argued that the sovereignty of the nation-state has reduced as a result of the increased mobility of international capital, creating an extensive and potentially disparate international trade agreements and the power of huge trans-national corporations; on the other hand, the nation-state has never been more invested in controlling human movement across its borders. ${ }^{166}$ Historically, nation-states have not always been so interested in controlling international human mobility. As Jonathan Torpey contends, when it comes to human mobility “...modern nation-states and the international state system have monopolized the legitimate means of movement." 167 Specifically, Torpey explains that the direct result of the nation-state's sole control over international human mobility is that people were:

\footnotetext{
"...deprived of ...the freedom to move across certain spaces....and rendered dependent on states and the state system for the authorization to do so...a critical aspect of this process has been that people have also become dependent on states for the possession of an identity from which they cannot escape and which significantly shapes their access to various spaces."168
}

\footnotetext{
163 Hollifield (2000, 137pp)

164 ibid $(2000,137-8 \mathrm{pp})$

165 Vanaja Dhruvarajan \& Jill Vicker (2002) Gender, race, and nation : a global perspective (Toronto University Press)

166 Basok (1996, 130-5pp)

167 Jonathan Torpey "Coming and Going: On the State Monopolization of the Legitimate Means of Movement" in Sociological Theory

November 1998 , vol. 16 , no. 3, pp. 239-259(21)

168 Torpey $(1998,239-242 \mathrm{pp})$
} 
In other words, the states and the existing international system of states have incrementally but indisputably put in place a system of states' universal control over the international movement of people. - Why has this come to be? How has this come to be? In order to answer these questions, it is necessary to discuss the current ubiquity of the national identity of individuals that inhabit this globe i.e. "the inescapable identities bestowed upon everyone by the states" and at the center of this concept is the identity document (e.g. the passport). ${ }^{169}$ An identity document involves certification intended to provide evidence of the identity of the person carrying it, and the passport is an example of such a document. The passport is an international identity documentation usually issued by a state government that intends to support the identity of the holder as a citizen of its boundaries. ${ }^{170}$ The passport as an identity document is primarily used by states to authorize movement across nation-state borders or by individuals to access various international spaces; more than ever before, it became deeply connected to the notions of "nation, race and state.".171

More purposively, the Canadian state has used the identity documentation of the international state system to control the mobility of particular groups of people, namely those that form the global south. For instance, since the early 1990's Canada not only adopted strict measures to dissuade refugees from reaching their borders but also introduced legislations that seriously eroded the basic principles of refugee protection in order to protect the sovereignty of the nation-state and to control 'illegal' migrants both within and outside of their borders. In other words, this state's incessant desire to control human movement brought about certain state

\footnotetext{
169 ibid (1998, 239-242pp)

170 For a detailed discussion of this please see Goodwin-Gill International Law and the Movement of Persons Between States 1978 (Oxford: Claredon Press:)

171 Radhika Viyas Mongia "Race, Nationality, Mobility: A History of the Passport" in After the Imperial Turn: Thinking with and through the Nation Edited by Antoinette Burton. Duke University Press (Durham \& Londọn: 2003) 196-97pp
} 
violations of refugees' rights in the process of upholding the state sovereignty. A prime example of such state violations is the Canadian Government's introduction of the identity document requirement in the 1990's. The Canadian Government made this demand on the grounds that Canada desperately needed to safeguard its national security and its economy against "undocumented bogus refugees" from the global south; among the government's claims were "such individuals were not only unsuitable migrants, but also were individuals mainly interested in pillaging Canada's generous social-welfare system"172. An analysis of the government's arguments uncovers the interconnectedness between Canada's history of racism and colonialism and the systemic discriminatory practices found in modern Canadian immigration policies especially refugee policy that are disguised under the banner of "nation-building." Before proceeding any further, it is necessary to introduce Canada's 1990's identity document requirement.

In 1993, the Canadian Government introduced subsection 46.04(8) of the Canadian Immigration Act. ${ }^{173}$ This provision of the Act states, "...an immigration officer shall not grant landing [...] unless the applicant is in possession of a valid and subsiding passport or travel document...."174 Simply put, this provision dictates that no Convention refugee be given permanent residence status without a 'satisfactory' identity document. There was no clear definition of "satisfactory identity document" put forward by the government, on the one hand this provision dictated that Convention refugees must have a valid passport or travel document; on the other hand, immigration officials had, and continue to have, the discretion to accept or

\footnotetext{
172 Razack (20001-183pp)

173 Brouwer (1999, 1-3pp)

174 Guy S. Goodwin-Gill \& Judith Kumin Refugees in Limbo and Canada's International Obligations Caledon Institute of Social Policy (Ottawa: September 2000) 17pp
} 
deny a refugee's identity paper as "satisfactory identity documents" e.g. some immigration officials were willing to accept birth certificates as identity documents while others did not. ${ }^{175}$

Immediately after this provision was introduced, Canada's Department of Immigration denied permanent residence status to recognized Convention refugees, the majority of whom were of Somali origin, because they were unable to provide "satisfactory" identity documents required. A few years later as Andrew Brouwer highlights

\section{“...more than 7,500 Convention refugees from Somalia and Afghanistan alone had been denied landing ...By the fall of 1998 , the total number had swelled to $13,000 \ldots$...This group incorporated a disproportionate number of women and children ....Indeed forty percent of these refugees were children."}

Thus, among other impacts which are discussed in chapter four of this thesis, this resulted in the creation of an economic under-class, consisting exclusively of refugees stuck in legal limbo. ${ }^{177}$ The next phase of the government's identity document requirement come into effect in 1997, as the new immigration program guidelines named Undocumented Convention Refugees in Canada Class (UCRCC). Some argue that this new program directly resulted from a Somali refugee's 1995 charter challenge to subsection $46.04(8)^{178}$ - Ahmed v. Ministry of Immigration and Citizenship. ${ }^{179}$ This Convention refugee's case was the first to challenge the validity of subsection 46.04(8) under the Canadian Chatter of Rights and Freedoms. Mr. Ahmed argued that the identity document provision in the Act was discriminatory against him and that it violated his equality rights i.e. this section treated him differently based on his nationality. In other words, since Mr. Ahmed's country of origin (Somalia) had no functioning government, at the time of his application for permanent residence, to issue him any valid identity documents, this provision

175 Interview \# 2

176 Brouwer (1999 1-5pp)

177 Razack (2000, 197-8pp) \& Tim Coates and Caitlin Hayward "The Cost of Legal Limbo for Refugees in Canada" 2004 (soon to be published) in Canada's Periodical on Refugees Vol. 22 Issue 2

178 Interview \# 7

179Ahmed, A.N Affidavit before the Federal Court of Canada - Trial Division. Registry no. IMM-324-95, September 15 
affected him adversely in a way that refugees from countries with functioning governments would not be impacted. As a result, the Ministry of Immigration and Citizenship offered to settle the case by giving Mr. Ahmed permanent residence status and accepting a sworn statement by Mr. Ahmed as his "satisfactory identity document." After the success of the Ahmed case, the other undocumented Convention refugees, still mostly Somalis, started sending sworn declarations to Citizenship and Immigration Canada leading offices. Unfortunately, the department decided that the undertaking in Ahmed vs. Ministry of Immigration and Citizenship only applied to Mr. Ahmed and would have no implication at all on policy. ${ }^{180}$ In other words, the federal Immigration Department was not prepared to accept sworn declarations from Convention refugees as an alternative to identity documents. Shortly after this, the government introduced the new program guidelines for undocumented recognized Convention refugees within the Canadian borders. The UCRCC guidelines stipulated that undocumented refugees would have to wait for five years from the date of their Convention refugee status determination by Canada's Immigration and Refugee Board before they apply for permanent residence status in Canada. ${ }^{181}$ This meant that the refugees, who prior to 1993 would normally wait for no more than a year to obtain Convention refugee status and thereafter immediately apply for permanent residence status, would now have to wait five years before they could apply. Also, it important to point out that the five year time period did not take into account the application processing time approximately two years from the date of the application. So what was the government's reasoning for imposing these restrictions?

One of the arguments that the Canadian Government presented involved protecting the nation's security against terrorists and war criminals pretending to be refugees. Was it necessary

180 Interview \# 7

181 Citizenship and Immigration Canada UCRCC program guidelines 
for the government to take these steps for security purposes? A respondent contends that while this was an interesting contention, it was an entirely baseless argument. There was no need to introduce the identity-document requirement for the purposes of national security; the Canadian Immigration Act contains separate provisions that allow for the removal of criminals or any individuals considered to be national security threat to the Canadian population, even those individuals with permanent status in the country. ${ }^{182}$ As Chantal Tie explains, special dispositions in the Immigration Act protect Canada's national security, and these security provisions stipulate that permanent residents may be ordered to leave Canada if it is shown that they misrepresented themselves on their application for permanent residence. ${ }^{183}$ For instance, the Canadian Minister of Immigration and Citizenship, joined by the Solicitor General of Canada, has the authority to issue a certificate of exclusion on the basis of security or criminal intelligence reports verifying that a person falls under certain inadmissible or removable categories in specific sections of the immigration Act. In the past, the Department of Immigration made such reports about permanent Canadian residents. ${ }^{184}$ Therefore, safety measures were put in place in the Immigration Act to assist the Canadian state in dealing with criminals who are pretending to be refugees. Thus, Canadian authorities could and should have dealt with criminals in others ways, without denying several thousand Convention refugees permanent residence status, which would have prevented the problems caused by the long waiting periods. Furthermore, "let us not forget that over ninety percent of the groups of refugees kept in limbo because of this legislation were Somali Convention refugees, eighty percent of whom were women and children." 185

\footnotetext{
182 Interview \# 4

183 Tie $(2000,202-214 \mathrm{pp})$

184 ibid (2000)

185(2000, 202-214pp). Also See the Aden Case Court File No. IMM 500/501-96
} 
Another one of the government's arguments was concerned with Canadian economic security threats and Canada's need to protect itself against welfare, unemployment and credit fraud, ${ }^{186}$ i.e. there were surmounting concerns about the numbers of asylum seekers that were coming into Canada. For example, elected members of the Canadian parliament, in the governing party and the official opposition party, as well as MPPs in Ontario, suggested that these "fake Convention refugees" only came to Canada to exploit its social welfare system and its lax refugee laws. ${ }^{187}$ The government decided to publish a report named "Welfare and Refugee Fraud" in 1993. According to this document, a number of refugees, mostly from Somalia, were on their way to Canada to "systematically pillage Canada's vulnerable and exposed social welfare system in an attempt to raise funds to support clan interests in the struggle for power in Somalia." 188

Based on the 'welfare and refugee fraud' rumors, the most damaging statements came from Canadian authorities. For illustration, the following statements referred to the report as well as the public's image of the Somali community in Canada:

“...Organized criminals are engaged in a 'systematic pillaging' of Ontario's welfare system to fund Somali warlords, provincial Liberals say, citing a confidential federal report.... The report said: This group is importing refugees to systematically pillage our vulnerable and exposed social welfare system in an attempt to raise funds to support clan interests in the struggle for power in Somalia [...] A single individual, using multiple names, can easily collect $\$ 100,000$ yearly and could get up to $\$ 300,000$, McLeod said.... The report states that the fraud is over tens of millions of dollars annually. We believe the report is credible,' she said.... The report suggests Canadians "run the risk of having our social net damaged beyond repair.... The Somali people are [...] opportunists whose use of confusion and misrepresentation is unparalleled except by the Gypsies of Eastern and Western Europe.... Our western and primarily Christianbased way of life has little meaning or relevance to these people. ${ }^{189}$

114Razack(2000,183-197pp

187Abel Giao Welfare and refugee fraud stories and their subsequent effect on the Somali community in the Ottawa area (MA thesis Carleton

University: 1995) 11-17pp

188 Giao $(1995,11-17 \mathrm{pp})$

189 Giao $(1995,11 \mathrm{pp})$ 
What about these claims? As one respondent observed, the welfare fraud stories were so far fetched that a few months later, the federal Minster of immigration, Sergio Marchi, renounced the "Welfare and Refugee Fraud Report."190 Marchi made the following statement, "I can not say that I have got evidence of a master plan that money was being defrauded out of the welfare system to support clan war in Somalia."191 During 1993, many refugee rights activists had publicly questioned the authenticity of such a report. ${ }^{192}$ In 1994, it came out that there was no evidence to support both provincial (mostly Ontario) and federal governments' claims that Somali refugees were looting the Canadian welfare system to support the Somali civil war; the claim of widespread welfare fraud, supposedly intended to finance clan war in Somalia, was based only on rumors, suspicion and prejudice. ${ }^{193}$

Another respondent exclaims "it is quite ironic" that on the one hand, there was the government who claimed the identity-document requirement was put in place to protect Canadians' tax money; on the other hand, the legislation itself caused economic problems for the Canadian tax payer nearly a decade later, making it almost impossible for the affected Convention refugees to find substantial employment to contribute to the Canadian economy. ${ }^{194}$ Newcomers (refugees and immigrants) in Canada generally experience difficulties in entering the labour force because of refusal of licensing and professional bodies to recognize many foreign credentials and because of discrimination on the part of employers. In addition, refugees have difficulty getting jobs because employers prefer permanent residents and Canadian citizens to Convention refugees, forcing the latter to resort to low paying jobs in the service industry.

\footnotetext{
190 For more details on this report see Abel Giao Welfare and refugee fraud stories and their subsequent effect on the Somali community in the Ottawa area (MA thesis Carleton University: 1995)

191 Giao (1995)

192 Interview \# 7

193 Giao $(1995,11-17 \mathrm{pp})$

194 Interview \# 8
} 
Refugees face serious obstacles regarding employment: racism, stereotypical attitudes of the Canadian public and lack of training opportunities. ${ }^{195}$ They do not have access to the kind of jobs that would help them better integrate into Canadian society as most of these jobs (i.e. professional) and training for these jobs is reserved for permanent residents and citizens. While this discrimination denied the refugees socio-economic development in Canadian resettlement, it also has negative repercussions for the Canadian economy. ${ }^{196}$ Further, given that there are significant differences between refugees and immigrants, studies show that refugees are more likely to depend upon welfare; this usually occurs during the period of waiting to become permanent residents. ${ }^{197}$ Also, studies show that after a refugee has been given permanent residence status, his/her welfare needs reduce substantially, ${ }^{198}$ which means that there would be significant savings in annual welfare payments. A decade after Canada introduced the identitydocument requirement for Convention refugees, the number of refugees in legal limbo almost doubled from 13000 to approximately 22,000 applicants and dependents, most of whom were waiting for permanent residence status for over five years. ${ }^{199}$ A decade of keeping refugees in limbo resulted in severe financial costs to both Convention refugees and Canadian taxpayers. These are the very economic problems that both provincial and federal governments supposedly wanted to avoid.

Yet another major federal government argument, accepted by members of society opposed to or ambivalent about the arrival of large numbers of non-European refugees, was based upon the cultural differences between the newcomers and the Canadian society at large.

195 Interview \# 7

196 Interview \# 6

197 Tim Coates and Caitlin Hayward "The Cost of Legal Limbo for Refugees in Canada" 2004 (soon to be published) in Canada's Periodical on Refugees Vol. 22 Issue 2

198 Coates \& Hayward (2004)

127 jbid (2004) 
For instance, Canadian federal government's officials would often publicly question whether

Somalis, being from such diverse background, would ever respect Canadian laws. In fact, in 1996

“...The federal Minister of Citizenship and Immigration states that because they have no ID, we will not grant these people permanent resident status until they have had time to demonstrate respect for the laws of Canada and for us to detect those who may be guilty of crimes against humanity or acts of terrorism...the message is clear - fraud will not be tolerated."200

Further, a year earlier the Canadian Government was criticized for having "...facilitated the acceptance of 26,000 refugees from the former Yugoslavia... [While] no such measures had been initiated to help Somalis; $; 201$ the same federal minister, in an attempt to respond to this criticism, "...explained that the Somalis' situation was less compelling owing to the fact that they were nomads who did not want to come to Canada anyway."202

A respondent suggests that the one of the implications of the government's cultural argument was based of the notion that:

"[...] since individuals from the global south are accustomed to tropical weather, they are incapable of adapting to the cold northern climate. Another implication, which concerned specifically Somali refugees, is that they too are different racially from the mainstream Canadian population, are Muslims, and the climate change is too harsh; therefore, these people must be here to steal from Canada and then leave." 203

While cultural disparity plays a significant role in integration, other factors "such as racism, xenophobia, language barriers, poverty, unemployment, and various forms of discrimination" 204 seem to carry considerably greater importance for successful resettlement. For instance:

"Cultural differences do not play as large a role as is commonly believed in the integration experience of most newcomers [...] For illustration: (1) Problems of

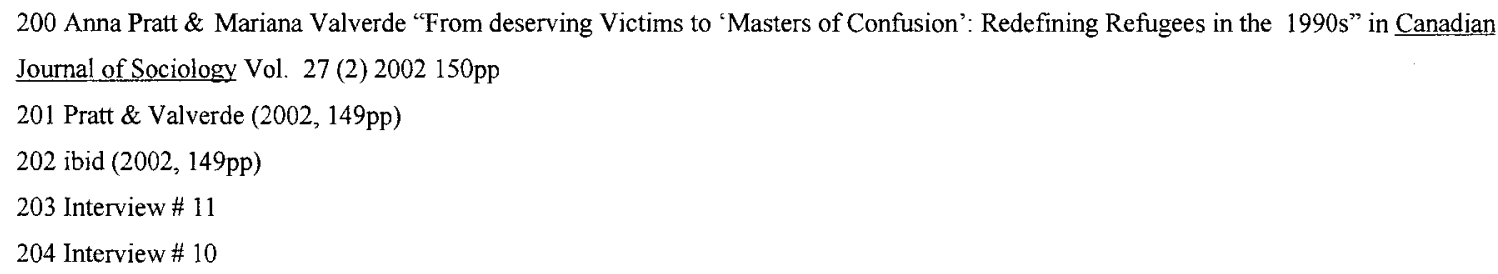


integration among newcomers from Somalia do not differ substantially from the integration problems of other newcomers, particularly other refugees [...] (2) Primary difficulties of settlement (long immigration process that carry a lot of uncertainty, poverty, unemployment, climate etc.) indicated by those [...] interviewed bore little relevance to the cultural background of Somali newcomers [...] (3) Cultural differences between young people and their parents, males and females are in many respects much stronger that the difference between 'Somali' culture and 'Canadian' culture [...] [Thus] cultural differences are much more perceived than real....205 The role of culture is often exaggerated (vis-à-vis other factors) in the integration experience of newcomers, both in terms of academic and settlement literature, as well as popular opinion."206

In sum, the Canadian Government's rationale behind the identity document requirement from Convention refugees was presented to the Canadian public via arguments of protecting Canada's social and economic welfare as well as its national security from individuals that had come to Canada to abuse its generosity; nevertheless as detailed by the above discussion, Canada's demand for identity documents from Convention refugees neither protected Canada's socio-economic wellbeing nor its national security. This is simply due to the fact that all the needed protective provisions of the Canadian immigration Act had already been put in place prior to the 1990s e.g. these provisions if need be would have assisted the removal of war criminals and those who might pose security threats to Canada. Furthermore, contrary to the government's claims, the identity document legislations of the 1990s kept thousands of potential taxpayers out of the work force and fueled racial tensions between the newcomer communities and the mainstream communities. As mentioned above the most devastating effects of the identity document requirement were experienced by the Somali refugee community in Canada as they were the group mostly impacted on by this shift in refugee policy in Canada. The next chapter discusses some of the problems this community had to face.

205 Mark Patton An Exploration of the Limits of Culture and the Integration of Experiences of Somali Newcomers in Ottawa. (1996, 1-3pp) Term Paper for Professor Scott Clark (September 1996). This paper discusses the primary factors of integration of newcomers to Canada, and focuses on Somali newcomers in particular 206 Patton (1996, 1-3pp) 


\section{Chapter 5:}

Somali-Canadian Community's Immigration Experiences (1993-2000): Some of the Challenges \& Impacts of the Identity Document Requirement

Census data from Statistics Canada indicate that more than fifty percent of new Canadians settle in Ontario. In Ottawa, for example, during the last two decades the percentage of the population whose first language was not English or French has increased to more than thirty percent. ${ }^{207}$ The Social Planning Council of Ottawa-Carleton estimated that between 1992 and 2003, over 45, 000 immigrants including refugees arrived at the Ottawa-Carleton region, ${ }^{208}$ and one of the largest groups of these immigrants groups was of Somali origin.

The overwhelming majority of Somalis came to Canada in the early 1990 s as refugees fleeing the civil war in Somalia. ${ }^{209}$ As discussed in the introduction, hundreds of thousands of Somalis fled their country since the outbreak of the civil war in 1991. After dealing with the trauma of being forced to leave their own country, Somali refugees had to adjust to the Canadian language, culture and ways of life. Somalis incurred systemic barriers in immigration, education, employment, housing etc., and these barriers proved to cause not only great frustration for the Somali community but also serious socio-economic hindrance. ${ }^{210}$ For example, the growing Somali community is considered to be one of the most disadvantaged and, at the same time, one of the most ambitious among the visible and ethnic minorities in Canada. ${ }^{211}$

According to a refugee case worker, some of the basic immigration difficulties that Somali refugees face upon arrival involve the immigration process. ${ }^{212}$ One of the initial problems members of this community face when they make a refugee claim in Canada deals with

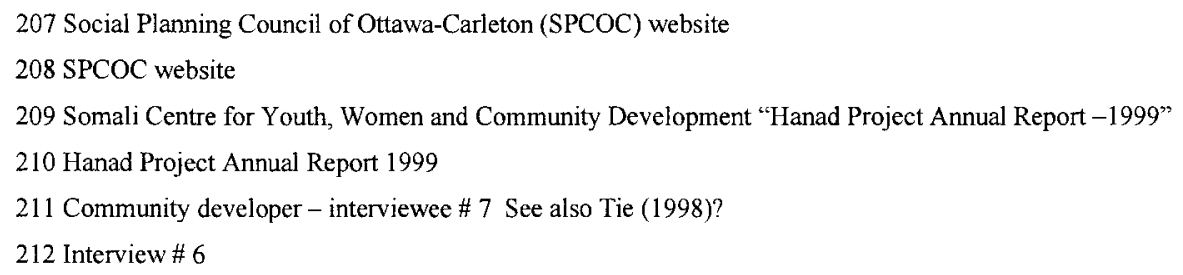


remembering exact dates and times when events have occurred. Undocumented refugees rely heavily on memory for important dates when completing immigration forms. ${ }^{213}$ Since the late 1980s this has been an important part of the refugee claim process in Canada as claimants upon their arrival in Canada have obtained permission to claim refugee status from Citizenship and Immigration Canada. ${ }^{214}$ Among other things, this means that refugees must complete several immigration forms at points of entry. Given that undocumented refugees rely heavily on memory for important dates and details when completing immigration forms i.e. these refugees face the task of remembering exact details of their lives and why/how these details relate to their refugee claim. $^{215}$ This is followed by the onerous task of convincing the Canadian Immigration and Refugee Board that their claim is legitimate. Difficulties in providing exact information on the dates of travel and the distance could lead to their claim being rejected based on lack of credibility. $^{216}$

More severe immigration problems that this community faced came as the direct result of Canada's identity document demand from Convention refugees in the 1990s. It seems now coincidental that this demand initially came into effect at a time when most of the undocumented Convention refugees came from Somalia. ${ }^{217}$ However, some argue that there is a direct causal relationship between the arrival of large numbers of Somali refugees in the late 1980s and early 1990 s and the creation of the more restrictive immigration provision that was specifically

\footnotetext{
213 Interview \# 9

214 It is important to note that this process has changed since the implementation of the Canada-USA Third Safe Country Agreement that came into effect in December 2004. The Canadian government now requires that refugee claimants who are coming through the USA to make their claim in the United States. For a detailed description of this agreement please see http://www.web.net/\%7Eccr/s $3 \mathrm{cregscommentsstandcomm.html}$ 215 Interview \# 9

216 Interview \# 9

217 Interview \# 11
} 
directed at Convention refugees. ${ }^{218}$ Studies show that since the early 1990 s, Somali refugees in Canada have been suspected of "welfare and refugee fraud", which prompted the Government of Canada to conduct extensive investigations. ${ }^{219}$ Furthermore, Canada's demand for identity documents from recognized Convention refugees seemed to single out Somali refugees, first denying them permanent residence status in 1993 and then (in 1997) imposing a five year waiting period before these refugees were eligible to apply for permanent residence status in Canada. ${ }^{220}$ In this respect, the Canadian Government's decision to deny permanent residence status to a large number of undocumented refugees recognized by the Canadian Immigration and Refugee Board as Convention refugees, the majority of whom were Somalis, has had adverse impact on the Somali community in Canada.

A refugee lawyer pointed out that perhaps one of the most pressing and stressful concerns for those refugees in "legal limbo" involved the fact that they had dependents at risk of dying in either their country of origin or in refugee camps in neighboring countries, ${ }^{221}$ i.e. the situation in Somalia was, and continues to be, extremely dangerous for civilians, and most of Somali refugees, who have fled to neighboring countries in East Africa. Among other things, this means that families (spouses and children) were separated while fleeing for their lives. ${ }^{222}$ According to the Canadian Immigration Act one must be either a Canadian citizen or a permanent resident of Canada in order to sponsor a close family member such as a spouse, child or parent, but a person with only a Convention refugee status (without permanent resident status) is not eligible to

\footnotetext{
218 Interview\# 11. For more details see Gio (1995)

219 Gaio $(1995,10 \mathrm{pp})$. Also See Mark Patton An Exploration of the Limits of Culture and the Integration of Experiences of Somali Newcomers in Ottawa. $(1996$, )

220 Interview \# 2 Also see Tie (1998, 202-214pp)

221 Interview \# 2

222 Interview \# 2
} 
sponsor his/her family members. ${ }^{223}$ There were some Somali Convention refugees who were waiting for landing for over eight years, which meant they could not sponsor any of their dependents (spouses and children) during the waiting period. 224

Another respondent contends the inability to sponsor their relatives became a major problem for those refugees who were single parents, with their spouses abroad (mostly in refugee camps in East Africa). Those Convention refugees who had to wait for years to become permanent residents would apply to sponsor their dependent children from overseas refugee camps, a process which normally takes twelve to eighteen months for the overseas visa offices to complete paperwork. ${ }^{225}$ These refugees' applications were often rejected because the dependent child had passed Citizenship and Immigration Canada's sponsoring age cut off. ${ }^{226}$

Moreover, those undocumented Convention refugees whose children met the age requirement for sponsorship often faced further bureaucratic obstacles. These included "finding minor technical faults in the application, extremely slow processing time, refusal to reply to communication, understaffed visa posts, hostile immigration and visa staff and demanding DNA testing from both the sponsor and the family members being sponsored. ${ }^{227}$ The biggest problem with the DNA testing, aside from being very time consuming, is that the process is very expensive and often tends to be financially overwhelming for single parents trying to sponsor several children (the average number of children in Somali family is five) and/or spouse. ${ }^{228}$ In particular, the sponsorship difficulties led to many Somali refugees developing mental health

223 Tie (2000)

224 Interview \#7

225 Interview \# 3

226 The Sponsor cut off age used to be under 19 years of age; however, it has been changed to 22 years or under in June 2002 (Citizenship and Immigration website)

227 Interview \# 4

228 Interview \# 10. Also see The Somali Center For Youth, Women and Community Development's Hanad Project Evaluation Reports (Sept. 1997-Aug. 2000) 
problems, such as anxiety and depression because they were separated from their families for so long, and suffered from post-traumatic stress disorders. ${ }^{229}$

In Canada those who are not citizens or permanent residents do not have equal access to education. In other words, refugees awaiting permanent residence have to obtain study permits from Citizenship and Immigration Canada in order to attend school. ${ }^{230}$ Prior to 2003, Convention refugees were not eligible for loans and bursaries. As witnesses testified in December 1996 in front of the House of Commons Standing Committee on Citizenship and Immigration:
“...to apply for the Ontario student assistance program, to be eligible you must be a Canadian citizen or permanent resident of Canada[...] to apply under the Canada Student Financial Assistance Act, it also says you must be a Canadian citizen or a permanent resident. That means a lot of students who've completed high school successfully are ineligible for scholarships or OSAP for any kind of training that would assist them in becoming productive members of Canadian society". 231

Also, Convention refugees must obtain a work permit to be eligible for work in Canada and work permits must be renewed annually, which often causes problems with employers who prefer workers who do not need work permit to work in Canada. ${ }^{232}$ Convention refugees and refugee claimants have distinct Social Insurance Numbers that show their immigration status, which further complicates the situation. ${ }^{233}$ This frequently translates into employers perceiving them as temporary residents of Canada and "risky" workers; as a result, these employers avoid hiring such individuals. Many employers, including federal and provincial governments, require their employees to be Canadian citizens or permanent residents of Canada. ${ }^{234}$ Convention refugees also face roadblocks to professional training programs and bank loans for small businesses.

229 Dr. Marta Young "Expert Report of Dr. Marta Young". This report was used in the Aden trial to argue the severe psychological effects that the identity-document requirement legislation has had on those impacted

230 Interview \# 8

231 "Evidence" Minutes of Meeting 33 of the Standing committee on Citizenship and Immigration (November, 1996)

232 Interview \# 4 also look at "Evidence" Minutes of Meeting 33 of the Standing committee on Citizenship and Immigration (November, 1996)

233 Interview \# 2

234 Interview \# 6 
Another set of problems arose from the fact that there was no standard interpretation of the government's definition of a "satisfactory" identity document and immigration officials had complete discretion whether to accept or reject the identity documents presented to them by Convention refugees. This problem relates to the much criticized issue of discretionary power held by immigration officers, whose biases towards racialized minorities often reflect those of the general public. One respondent explained that the most difficult part for all involved (e.g. immigration/refugee lawyers, community rights activists and the impacted groups) was the ambiguous definitions of "satisfactory" identity document." 235 Another refugee lawyer recalled her experiences regarding this provision as being very frustrating because, "...It's a problem of hit and miss in terms of which documents are accepted by which immigration officer."236

A manager of settlement services in an Ottawa refugee and immigrant serving NGO remembers her frontline refugee workers complaining about this hit and miss problem with identity documents from Somalia, because the documents were in Italian and not in Somali. The immigration official in this case did not understand why or how Somali refugees had identity documents in Italian. Therefore, "the officer asked when the client had been to Italy and why have they not put that in their application for permanent residence."237 Obviously, this officer was not aware of the fact that Somalia prior to 1960 was partially colonized by Italy and that many of the Somali identity documents are in Italian as result of the colonial administrative system that was left behind by the Italians. ${ }^{238}$

Another respondent remembers a Somali mother of six who had birth certificates for all her children; however, only three of the children's birth certificates were accepted and the rest 
refused. ${ }^{239}$ According to this respondent, when the client demanded an explanation, she was told only that half the documents she submitted "looked false" to the immigration officer and was provided no further explanation for rejecting her documents.

In short, the Somali community has faced multiple problems as a result of the Canadian government's imposition of the identity-document requirement. The main areas impacted by this legislation included: (1) Denial of family reunification; (2) Social and Economic impacts; (3) Problems of Employability; (4) Lack of Access to Education; (5) Denial of Healthcare Benefits; (6) Political impacts: lack of voting rights as well as lack of the right to run for office; and (7) Restrictions on mobility rights. ${ }^{240}$ It is beyond the scope of this thesis to discuss all of these impacts in detail; however, the above discussion touched on the issue of family reunification as well as employment and education problems, as these were the most critical issues that the immigrant community encountered. Also, this chapter has shed some light on the scope of the identity document problem in the Somali community, and highlighted the adverse impacts on Somali Convention refugees. The next chapter discusses the Somali refugee community's activism against this injustice.

239 Interview \# 6

240 Pretrial Conference Memorandum of Plaintiffs (Aden Case: Court File No. IMM 500/501-96) 


\section{Chapter 6:}

Resistance: the Struggle towards Substantive Equality

As discussed earlier, in Canada, Somali refugees suffered extensive difficulty being accepted because of the changes to the Immigration Act that came into effect in 1993. According to the Department of Immigration

$$
\begin{aligned}
& \text { "...by the year } 1996 \text { approximately } 7,500 \text { Convention } \\
& \text { refugees were [...] unable to get landed because they lacked } \\
& \text { identity documents [...] Ninety percent of these refugees were } \\
& \text { of Somali origin, forty percent [of whom] were women and } \\
& \text { forty percent [of whom were] children under the age of } \\
& \text { sixteen."241 }
\end{aligned}
$$

This chapter discusses the Somali refugee community's political and legal mobilization in Canada, which came about as a direct response to the Canadian Government's imposition of restrictive immigration provisions (namely: s. 46.04(8) of the Immigration Act and the 1997 Undocumented Convention Refugee in Canada Class program guidelines) regarding undocumented Convention refugees.

An Executive Director of an immigrant and refugee serving organization in the Ottawa area, who worked with Somali refugees for over a decade, remembers the fragmentation of the Somali community members during the early years (late 1980s-early 1990s) of their arrival. The Somalis, recently arrived and an internally-divided refugee community with low economic integration, had little involvement in the public sphere and were confronted by a negative political environment; naturally, these people experienced substantial difficulties in establishing cohesive and durable community organizations. ${ }^{242}$ However, the activism surrounding the identity-document requirement necessitated this highly divided community to come together to fight this legislation and seek substantive equality in Canada. In 1993, in this country, the

241 Tie "Section 46.04(8) Identity Documents Constitutional Challenge Settled on Consent in Federal Court - Trial Division" in IMMGRATION LAW REPORTER (December 2000) 202pp

242 Interview \# 6 
Somali refugee community found itself with a common political project: the quest for substantive equality. ${ }^{243}$ This, in turn, promoted the associational life and the unity of the community. It enabled the community to pursue political and legal mobilization against prejudiced immigration policies. Thus, a Somali-Canadian respondent suggested that the introduction of the 1993 amendments to the Immigration Act served as a catalyst, uniting the fragmented Somali refugee community. This emergent solidarity became the first step in the community's political and legal mobilization. ${ }^{244}$ From the mid 1980s until 1993, a number of Somali community agencies across Ontario (mostly in Toronto and Ottawa), emerged, serving specific groups within the Somali community. These agencies were based on clan, gender, region or age group and organizations named after a specific group tended to provide services only to that particular group. ${ }^{245}$ However, this changed shortly after the 1993 implementation of s. 46.04(8) of the Immigration Act; these changes impacted the Somali community as a whole. One of the initial changes took place in Toronto in July 1993, when a cross-section of Somali organizations in the Municipality of Metropolitan Toronto founded a Somali community organization named Mideynta (to unify). ${ }^{246}$ This organization was created by factions of the community who were initially opposed to associate with each other because of the war in Somalia, and these included community organizations that were clan oriented (i.e. they used to attend to the needs of only certain clan groups in the Somali refugee community in the Toronto area), and young men and women who were tired of the divisions in this community and the lack

243 Interview \# 6

244 Interview \# 6

245 Interview \# 11

246 Mideynta is a Somali Community organization based in Toronto, which provides basic settlement services for the Somali community in Toronto in order to help them better integrate into Canadian society. The Center has been around since the early $1990 \mathrm{~s}$ and has been recognized by both the Somali community and the Canadian Government for its efforts and work in assisting the community with immigration and identity document problems. As well, other NGO service providers and provincial/municipal agencies across the province of Ontario have commended Mideynta for its effective organization that is dedicated to improving the lives of all members of the community. 
of political voice of the Somalis in Canada in general. ${ }^{247}$ Mideynta was specifically instrumental in assisting the community in its struggles against the identity document requirement. For instance, in 1997 this organization provided tremendous support to the African Canadian Legal Clinic in bringing "successful legal action on behalf of Ms. Hawa Khalif Said, one of the thousands of Somalis ...in immigration limbo." ${ }^{248}$ In this case the federal court overruled the Department of Immigration's initial decision to deny Ms. Said permanent residence status based on her lack of identity documents, and "ordered that the matter be sent to a second officer for redetermination...[And] the second officer to exercise their discretion considering all of the circumstances of the case. ${ }^{, 249}$ It is important to highlight that in this case the court did not rule that Ms. Said be permitted to submit statutory declaration as an alternative to identity documents, which the federal court did order in the Charter challenge case discussed later in this chapter.

Another respondent, a refugee lawyer, talked about similar experiences in Ottawa, where a number of small Somali community agencies in the Ottawa area took parallel steps. One of the main goals for the unification of these groups was to get the fragmented Somali groups to cooperate in demanding substantive equality for the community. ${ }^{250}$ Another goal was to help undocumented Somali refugees to become permanent residents and to help them through the difficulties of waiting for permanent residence status. A community organization director points out how the Somali community leaders took significant steps to deal with the identity-document crisis and how these community leaders intervened on the behalf of both individual cases and

247 interview \#6

248 African Canadian Legal Clinic "ACLC wins test case for Somali Refugees" for more information on this case see http://www.aclc.net 249 ibid

250 Interview \# 9 
general policy. For example, these leaders made numerous pleas to the department of Citizenship and Immigration officials. ${ }^{251}$

Another respondent highlighted the initial movement in the Somali community's attempt. One of the community's major attempts to solve the identity-document problem came out of a meeting held in Ottawa in 1995. In this meeting, the community leaders met with immigration officials and discovered that the Department of Immigration had no intentions of landing Somali undocumented Convention refugees, and that the department was considering implementing even more restrictive measures against Somalis. ${ }^{252}$ This triggered a series of Somali community gatherings in Ottawa and Toronto that focused on these particular issues. After long consultations with immigration lawyers, refugee activists and international human rights groups, the community representatives wrote to and met with immigration department representatives to suggest setting up a Somali Council of Elders. The community leaders suggested that this council could work with the immigration department in the process of landing undocumented Somalis. ${ }^{253}$ "This would have been a Council representing a cross-section of the Somali community and would be set up for the purpose of establishing identity of the undocumented individuals. ${ }^{, 254}$ In order to increase its credibility in the eyes of the Department of Immigration, the community readied itself to continue identifying individuals who had committed war crimes. More specifically, the new Council of Somali-Canadian Elders' purpose was to further assist the department in this endeavor. ${ }^{255}$ Unfortunately, department officials always expressed a deep

251 Interview \#10

252 Interview \# 6

253 Interview \# 6 Almost all interviewees remarked on the level of organization presented towards the identity requirement issues by this otherwise divided community

254 Interview 11

255 Interview \# 11 
disinterest in such proposals from the community, because they perceived that the measures would transfer departmental authority into the hands of these groups. ${ }^{256}$

Another respondent remarked on how the community leaders and organizations came together to deal with the crisis at hand and assisted the community in reaching out to large interest groups with similar concerns about refugee rights. The groups utilized the channels of lobbying and interest group politics to influence Canadian government's refugee policy decisions. $^{257}$ This helped the community have a stronger voice in the public, filtering its information through the proper channels to make the Canadian authorities pay attention to its needs. In November 1996 a proposition of further regulations (Undocumented Convention Refugee in Canada Class, which came into effect in January 1997 as discussed in chapter three of this thesis) by Citizenship and Immigration Canada, regarding the landing of undocumented Convention refugees, proved to be a cause of stress for a number of groups. The representatives of the community, with the assistance of national and international human rights activists presented their concerns with the legislation to the Standing Committee on Citizenship and Immigration hearings in November 1996, with an emphasis on the negative impacts of the identity-document requirement, specifically, the five-year waiting period. ${ }^{258}$ After hearing the extensive details of the hardship this had so far caused and the serious potential for further adversities for those impacted, the Committee recommended the following:

“(1) ...The waiting period before which a recognized Convention refugee may become ...eligible for landing should be reduced to two years following recognition as a Convention refugee by the Immigration and refugee Board... (2) Children overseas of an individual landed as a member of the Undocumented Refugees in Canada Class (UCRCC) should be sponsorable as long as they were under 19 years of age at the time the initial application for landing as a Convention refugee was submitted...(3) The government should consider allowing spouses and dependants abroad of recognized Convention refugees to come to Canada on Minister's Permits during the waiting period under the UCRCC...(4) The government should develop

256 Interview \# 4

257 Interview \# 10

258 Interview \# 10 
guidelines for immigration officers regarding documents that are satisfactory as identity documents for the purpose of landing in the absence of an acceptable passport or travel document...(5)The government should work with the interested parties and the affected communities to develop expertise in understanding and assessing documents relevant to proving identity...(6) in order to expedite landing, informal processing of application by members of UCRCC should begin six months before a person is eligible as a member of the class...(7) Citizenship and Immigration Canada should ensure that sufficient resources are devoted to processing applications by members of UCRCC so that processing time can be concluded as fast as possible, with a target of six months...(8) In order to expedite the reunification of ...families, informal processing of families abroad should begin at the same time as it begins in Canada, unless families are brought forward on Minister's Permits., 259

The community also had a big hand in making the identity-document requirement legislation the target of severe criticism by Canadian human/refugee rights activists and the United Nations High Commissioner for Refugees because of the impact this legislation had on recognized Convention refugees. For instance:

\begin{abstract}
"In 1995, Canada was examined by the UN Committee on the Rights of the Child... In its Concluding observations, under Principal subjects of concern, the Committee stated at Paragraph 13: ...The Committee recognizes the efforts made by Canada for many years in accepting a large number of refugees and immigrants. Nevertheless, the Committee regrets that the principles of nondiscrimination, of the best interests of the child and of the respect for the views of the child have not always been given adequate weight by administrative bodies dealing with the situation of refugee or immigrant children. It is particularly worried that...insufficient measures aimed at family reunification with a view to ensure that it is dealt [with] in a positive, humane and expeditious manner. The Committee specifically regrets the delays in dealing with the reunification of the family in cases where one or more members of the family have been considered eligible for refugee status in Canada....260
\end{abstract}

Unfortunately, neither the international criticism of these policies, nor the recommendations of the Standing Committee were taken into consideration by the Canadian Government. In fact, the government went ahead with the implementation of the five-year waiting period policy. ${ }^{261}$ Having exhausted all of the political channels available, the Somali community, represented by three Community Legal Aid Clinics in the Ottawa area, launched a federal charter challenge to Subsection 46.04(8). Before discussing the details of this Charter

259 Minutes from meeting \# 32 of the Standing Committee on Citizenship and Immigration Proposed recommendation regarding the landing of undocumented Convention refugees (1996) 2-10pp

260 Canadian Council for Refugees website http://www.web.net/\%7Eccr/limbo.htm

261 Interview \# 10 
challenge, a brief background of the history of the Canadian Charter of Rights and Freedoms is in order.

\section{The Charter Challenge:}

The Canadian Charter of Rights and Freedoms was part of the constitutional amendments of $1982 .^{262}$ It is generally understood that a constitution provides the essential framework for orderly government as well a legal structure for the conduct of formal relations between the public and their government. The Canadian constitution is not a single document as in the United States, but an evolving social contract including unwritten elements, such as in British constitutional conventions, established customs, tradition and precedence. ${ }^{263}$ The concept of responsible government, in which the Cabinet is collectively accountable to the elected House of Commons, is a fundamental unwritten element of Canadian parliamentary democracy at the federal and provincial levels. ${ }^{264}$ The Canadian constitution's foundation is the Constitution Act of 1867, originally the British North America Act of 1867, and the Constitution Act of 1982 . The Constitutional Act of 1982 transferred formal control over the Canadian constitution from Britain to Canada, introduced procedures for constitutional amendment, and entrenched a Canadian Charter of Rights and Freedoms. The charter replaced the Canadian Bill of Rights, an Act of the Canadian Parliament passed in 1960 to outline basic civil liberties with limited judicial effectiveness. ${ }^{265}$ In contrast, the charter is a much more powerful legal tool that applies to both federal and provincial government equally.

Moreover, the Charter has had significant use in the area of administrative law, particularly in judicial review. Specific sections of the Canadian charter instruct the courts to

262 David Milne The Canadian Constitution: (Toronto: J. Lorimer, 1991) 235-250pp

263 Allan Caims $(1970,301-5 \mathrm{pp})$

264 Cairns $(1970,301-5 \mathrm{pp})$

265 Milne (1991) 
invalidate any legislation that conflicts with the provisions of the charter. With the exception of provisions which affirm existing rights of the Aboriginal peoples of Canada, sections 7 and 15 are the only provisions of the Charter that specifically apply to a wide range of public policy in relation to equality rights. ${ }^{266}$ Numerous groups, including Aboriginal communities in Canada and the Canadian women's rights activists, recognize the importance and usefulness of explicit inclusion within these provisions of the Charter. Thus the story of the equality rights provisions in the Charter involves groups who have sought recognition and mobilized that recognition to extract favorable policy outputs from all levels of government. For example, in Miron $v$. Trudel the court ruled that distinction is discriminatory if it is capable of perpetuating the view that the individual adversely affected is less capable of deserving concern, respect and consideration from the point of view of a reasonable person. ${ }^{267}$

Likewise, since the Somali community had no success after years of trying to impress upon Canadian authorities the inherent discrimination found in the identity document requirement, they decided to seek equality rights through the courts by launching a constitutional challenge against the Canadian government. This means that the plaintiffs, undocumented Somali Convention refugees, argued that s. 46.04(8) of the Immigration Act makes a distinction against them contrary to the Canadian Charter of Rights and Freedoms. Their argument has

266 Interview \# 3

267 See Miron v. Trudel "Exclusion of unmarried partners from accident benefits available to married partners under the policy violates s. 15(1) of the Charter. Denial of equal benefit on the basis of marital status is established in this case, and marital status is an analogous ground of discrimination for purposes of s. 15(1). First, discrimination on that basis touches the essential dignity and worth of the individual in the same way as other recognized grounds of discrimination violative of fundamental human rights norms. Second, marital status possesses characteristics often associated with recognized grounds of discrimination under s. 15(1). Persons involved in an unmarried relationship constitute an historically disadvantaged group, even though the disadvantage has greatly diminished in recent years. A third characteristic sometimes associated with analogous grounds, namely distinctions founded on personal, immutable characteristics, is also present, albeit in attenuated form. While in theory, the individual is free to choose whether to marry or not to marry, in practice the reality may be otherwise. Since the essential elements necessary to engage the overarching purpose of s.15(1) -- violation of dignity and freedom, an historical group disadvantage, and the danger of stereotypical group-based decision-making -- are present, discrimination is made out." (John O. Miron and Jocelyne Valliere (Appellants) V. Richard Trudel, William James McIsaac and the Economical Mutual Insurance Company (Respondents)\} 
centered on the absence of a functioning government in Somalia since the fall of the Siyad Bare regime in 1991 and the eradication of principal identity papers as result of the civil war. These Convention refugees had no way of obtaining "satisfactory identity documents" from their country of origin, and the Department of Immigration refused to accept sworn declarations as an alternative to identity documents; thus, undocumented Somali Convention refugees alleged that the adverse effects were based on national origin and race. ${ }^{268}$ The plaintiffs sought that in the cases where Convention Refugees have no identity documents and are able to obtain identity documents from their country of origin, this section be interpreted so that the Sworn statement of an applicant attesting to his/her identity satisfies the requirement. ${ }^{269}$

The specific legal contentions of this group were numerous; however some of the key claims included the fact that all of them were determined Convention refugees by the Immigration and Refugee Board of Canada and had the same country of origin (Somalia). ${ }^{270}$ Secondly, after having been determined Convention refugees they all applied for permanent residence status in Canada. However, the federal Department of Immigration had made the decision to suspend their applications because the applicants were unable to provide a "valid and subsisting passport or travel document or a satisfactory identity document pursuant to s. $46.04(8)$ of the Act"271 even though the Act does not specify what exactly constitutes "satisfactory identity documents."272 Thirdly, there has been an ongoing civil war in the plaintiff's country of origin and all passports/travel documents issued by the fallen regime have expired; there is no body of government that can issue identity documents, and there is no way of getting documents that may

\footnotetext{
268 Aden Court File No IMM 500/501-96

269 Aden Court File No IMM 500/501-96d

270 Interviews \# $(2,3,9)$ with refugee lawyers

271 Court File No IMM 500/501-96

272 interviews $(2,3,9)$
} 
have survived the war out of that country as the defendant's witnesses have testified during Examinations of Discover. Fourthly, the Canadian Government did not conduct any studies to examine whether the security of Canada would be jeopardized by giving permanent residence status to undocumented Convention refugees before the introduction of s. 46.04(8) of the Act. ${ }^{273}$ There were no "discussion papers" prepared which would indicate that there would be security problems. There was/is no evidence regarding problems arising from the landing of undocumented Convention refugees being an "urgent and considerable issue" as was the government's rationale behind this requirement. ${ }^{274}$ As well the defendant's witnesses have also testified that within the first two years of the introduction of s. 46.04(8) of the Act, there were approximately eight thousand principal applicants and over ninety percent of these were Convention refugees from Somalia. Over eighty percent of these were women and children, and the number of the affected group was expected to more than double within a four years period. ${ }^{275}$ Lastly, the government claimed that Citizenship and Immigration Canada has issued an Operations Memorandum stating that recognized Convention refugees in Canada have the option to "file statutory declarations as a satisfactory proof of their identity;" 276 however, the position of the plaintiffs was that "Operations Memorandum is an unsatisfactory mechanism for the landing of Somali Convention refugees and...is incapable of being exercised in a constitutionally permissible manner." ${ }^{277}$ Further, the plaintiffs' lawyers were ready to present

$$
\begin{aligned}
& \text { "...evidence to show that the wide and unstructured discretion given to the } \\
& \text { immigration officers reviewing the statutory declarations...the Operations } \\
& \text { Memorandum is a guideline only and does not bind the officers in the exercise }
\end{aligned}
$$

\footnotetext{
273 Aden Court File No IMM 500/501-96

274 Tie $(2000,202-215 p)$

275 Interview with lawyers of the community

276 Court File No IMM 500/501-96 (1-6pp)

277 Court File No IMM 500/501-96 (5-6pp)
} 
of their discretion...the discretionary decision makers have a high potential for making biased decisions on the basis of race and national origin.,"278

(7) Finally, at the trial the plaintiffs were ready to establish the devastating consequences that they had suffered due to their lack of status (i.e. psychological trauma separation from immediate family members, restrictions on rights to travel outside of Canada and the socio-economic consequences that arise from lack of access to employment, training for employment, higher education and difficulty establishing small businesses). ${ }^{279}$

In response, the defendant (Canadian Government) argued that the government was very much concerned about the situation of the undocumented refugees in Canada who could not be lande $d^{280}$. For instance, the government argued that "the Undocumented Convention Refugees in Canada Class (UCRCC) program guidelines were created to allow undocumented refugees from Somalia and Afghanistan to apply for landing."281 The defendant also contended that under the UCRCC program guidelines undocumented Convention refugees were allowed to apply for landing after a waiting period of five years, at which time these refugees were permitted to be "landed on the basis of a statutory declaration." ${ }^{282}$ The government also stated that Citizenship and Immigration Canada had introduced an Operations Memorandum in an attempt to alleviate

278 Court File No IMM 500/501-96 (5-6pp)

279 More specifically, the plaintiffs' Charter claims were based on the following arguments: (I)Under section 15 of the Charter, the Plaintiffs ... argue that they have been denied a right to equality before the law because they are required to produce original identity documents which are unavailable to them because of their national origin ... as follows: (1) Section 46.04(8) of the Act fails to take into account the Plaintiffs' disadvantaged position within Canadian society, which results in differential treatment; (2) This differential treatment is on the basis of race, gender and national origin; (3)The differential treatment discriminates against the Plaintiffs by imposing a burden upon the Plaintiffs, and by withholding substantial benefits from the Plaintiffs...the withholding of immigration status from the Plaintiffs promotes the view that they are less worthy of recognition as human beings and not equally deserving of concern, respect and consideration, (Aden court file document). Further, under section 7 of the Charter, the Plaintiffs argued: (1) That their rights to security of the person has been threatened by the state action. Section 7 protects both the physical and psychological integrity of the individual and the courts have recognized that this protection extends beyond the criminal law, (2)That there has been State-imposed psychological harm visited upon the Plaintiffs, which is both serious and profound; (3)That State-imposed separation from children and spouses constitutes a serious interference with the psychological integrity of the Plaintiffs. Further, the Plaintiffs are stigmatized by their lack of immigrant status, being perceived publicly as unworthy, deceitful or criminal; (4) That the stigmatization, combined with the disruption of family life constitute a restriction of security of the, (Aden court file document)

280 Court File No IMM 500/501-96

281 Court File No IMM 500/501-96

282 Court File No IMM 500/501-96 
the situation of undocumented refugees, and that previous to this memorandum "very few statutory declarations were accepted as satisfactory identity documents...and ...there was no evidence to dispute the plaintiffs' claim that there is still considerable inconsistency in its application across the country.",283

In December 2000 the charter challenge came to an end when an agreement was reached between the two parties. This agreement was initially operationalized as a Citizenship and Immigration Canada Operations Memorandum. ${ }^{284}$ The Operations Memorandum has since been built-in into the "Immigration Regulations in section 171."285 This agreement known as the Aden Agreement allows undocumented recognized Convention refugees to present sworn statutory declaration as a substitute for identity documents with their applications for permanent residence status in Canada. ${ }^{286}$ In other words, a statutory declaration in the Aden Agreement refers to "a statement relating to the identity of undocumented Convention refugees applying for permanent residence status in Canada."287 Further each undocumented applicant must submit two sworn declarations for him/herself and their dependent children (less than eighteen years of age). One of the sworn statements must be made by the applicant and the other must be made by a witness, who knew the applicant in his or her country origin, or habitual residence, who is either a Canadian citizen or a permanent resident of Canada or anyone else whose testimony may be

\footnotetext{
283 Court File No IMM 500/501-96

284 Harry Kitts and Hamdi Mohamed Protecting the Unprotected: Submission to the House of Commons Standing Committee on Citizenship and Immigration with respect to the proposed Regulations under the Immigration and Refugee Protection Act February 14, 2002 2-40p. Citizens for Public Justice

285 See Kitts \& Mohamed (2002, 3-4pp). Also, section of the regulation states "171. (1) An applicant who does not hold a document described in any of paragraphs $48(1)(a)$ to (h) may submit with their application: (a) identity documents issued outside Canada before the entry of the person to Canada; and (b) a statutory declaration made by the applicant attesting to their identity, accompanied by (i) the statutory declaration of a Canadian citizen or permanent resident attesting to the applicant's identity, or (ii) the statutory declaration of an official of an organization representing nationals of the applicant's country of nationality or former habitual residence attesting to the applicant's identity."

286 Tie $(2000,202-214 \mathrm{pp})$

287 ibid (2000)
} 
deemed fitting by an Immigration Officer. ${ }^{288}$ In addition, in cases where refugees do not have any witnesses who knew them in their country of origin or habitual residence, the agreement allows that the refugees submit a sworn statement from "a credible organization that can swear to the applicant's identity., 289

This was in many ways a major victory for the affected individuals as it meant that they would not be denied permanent residence status in Canada based solely on their lack of identity documents as was stipulated in $\mathbf{s . 4 6 . 0 4 ( 8 )}$ of the previous Immigration Act. ${ }^{290}$ Furthermore, under this agreement, undocumented Convention refugees would not have to wait five years to apply for landing as was the requirement under Undocumented Convention Refugee in Canada Class. ${ }^{291}$ Refugee rights activists have argued that the decision in the Aden Agreement "has been essentially incorporated into the Regulations...with some significant changes which make it more restrictive." 292 For example, critics have highlighted that one of these changes involves the second sworn declaration, which

\footnotetext{
“...under Aden can be made by a Canadian citizen or permanent resident or any other person deemed acceptable in the discretion of the officer...the latter phrase has been omitted in the Regulations and ... in section 171(1)(a), the word and has been inserted prior to clause (b), implying that Convention refugees would now have to submit both identity documents and statutory declarations... in the Aden Agreement the statutory declarations were to be submitted in lieu of identity documents...further, the value of the Aden Agreement is highly inconsistent in applications for landing....even after more than a year since Aden was agreed to, there have been many reported instances where Citizenship and Immigration Canada officers were not even aware of the existence of the Aden... there were other reported instances where officers knew of the Order, did not follow it, and therefore did not land people. These inconsistencies raise concerns ....as this maintains the level of legal limbo for refugees, with all its attendant problems." ${ }^{293}$
}

\footnotetext{
288 Kitts \& Mohamed (2002, 3-5pp)

289 ibid (2002, 3-45p)

290 Tie (2000)

291 Tie $(2000,202-214 p p)$

292 Kitts \& Mohamed (2002, 3-5pp)

293 ibid (2002, 5-6pp)
} 
In sum, the above discussion has highlighted that Somali refugees were the main target of this legislation, and that this initially fragmented community united to fight the discriminatory impacts of Canada's identity document requirement through the courts. In addition, this discussion brings to the forefront a major contradiction found in Canada's liberal democratic institutions, i.e. on the one hand the executive branch/level of the Canadian Government introduced policies that discriminated against the aforementioned group and denied them basic equality rights; on the other hand, the judiciary branch of the same government (in this case the Federal Court of Canada) assisted these refugees to stand up to the Canadian Government and reversed the discriminatory policy by simply upholding the equality provisions found in the Canadian Charter of Rights and Freedoms. So, what does this mean? Or more specifically, what does it say about Canada as a liberal democracy?

As discussed in the second chapter of this thesis, Sociologists as well as Political Scientist have argued that the answers to such questions lie in Canada's (i.e. the dominant Canadian society's) commitment to liberal democratic values (e.g. the entrenchment of equality rights provisions in the Canadian Constitution) and the maintenance of illiberal and xenophobic attitudes towards people of color at the same time. In other words, the explanation lies in the existence of a phenomenon referred to as democratic racism, which can be defined as an ideology that brings about a certain cognitive dissonance that does not only justify, but also perpetuates the simultaneous existence of two apparently conflicting values. ${ }^{294}$ On the one hand, Canada as a democratic nation is committed to liberal and egalitarian values such as fairness, justice and equality; on the other hand, these values are contradicted by attitudes and behavior (e.g. negative feelings about people of color) that often lead to the differential treatment and discrimination against ethnic minorities. Among other things, this means that while the Canadian

${ }^{294}$ Richmond (2001, 15pp) 
Government often advocates for the "freedom of movement for its citizens" (i.e. the ability to live, work and travel in any nation in the world and enjoy certain rights and privileges); this government did not extend the same rights and privileges to recognized Convention refugee within its borders. For example, Canada's introduction of identity document requirement to stem the flows of refugee movement from third world countries while accommodating the arrival of European refugees (e.g. Kosovo) brings to the forefront these competing ideologies. More specifically, this country's exerted efforts in stopping migrants from global south to reach its borders or its repeated attempts to deny basic rights to protected peoples within its borders; continuously undermines fundamental ethics of human rights that the citizens of this country theoretically hold dearly.

Further, the nuts and bolts of "liberal political philosophy" is often contradicted by Canada's exclusionary immigration and refugee policies e.g. the 1990 s identity document requirement, which had severe discriminatory impacts on specific groups as the findings of this thesis have highlighted. Among other things, this means that Canada, along side other 'liberal democracies', while claiming to uphold fundamental liberal principles, engages in introducing immigration and refugee legislations and laws that essentially legalize racism under the banner of protecting the sovereignty of the Canadian state and the security of the nation's economic and social welfare. This line of thinking is very problematic for, in its selective and narrow application of liberal principles of human rights, it does not only violate core democratic values, but it also puts state rights before human rights. Perhaps the most disturbing dimension of this rather selective application of liberal democratic ideology is that it reveals a rather dark side of a white settler society that is overly preoccupied with controlling the 'colonized other'; hence the repeated institutionalization of immigration and refugee laws and policies that essentially rest on 
what Edward Said called Orientalism, "a discourse through which the colonial other or the orient is represented by the colonizer as subordinate and inferior." $" 295$ In other words, in today's postmodern, post-Cold War, globalized world, in which multi-cultural, multi-ethnic, liberal democracies like Canada practice systemic discrimination against ethnic minorities, the discourse of Orientalism re-invents itself through immigration and refugee policies that are centered on economic gains and are aimed at overriding democratic liberal ethics such as fairness and equality.

295 For an in depth discussion see Said's Orientalism (1978) New York, Vintage Books 


\section{Conclusion:}

Canada is often described as a nation of immigrants. In fact, during the last four decades the number of Canadians who were born outside of Canada has increased significantly. In particular, Canada has had a reputation of being one of the most welcoming countries in the world when it comes to refugees and protected peoples. Nevertheless, this reputation has been eroding incrementally since the early $1990 \mathrm{~s}$ and this has been a direct result of the shift in Canadian refugee policy during the last decade of the twentieth century. This thesis explores the motivations behind limitations drawn between those "who can and those who can not enter the nation-state", in this case Somali undocumented refugees in Canada. Also, this thesis sheds some light on some of the ways this shift in policy has impacted these refugees in this country. In particular, this thesis has evaluated the situation of undocumented Convention refugees in Canada since s. 46.04(8) of Canada's Immigration Act (the identity document requirement) came into effect in 1993 as well as the underlying rationale for the introduction of this provision. Lastly this thesis documents the legal and political mobilization that brought together the fragmented Somali community in their struggle against the restrictions that were imposed upon them.

Thus, this thesis begins with a discussion of the dynamics of migration with respect to tensions that arise between refugees' human rights and the sovereignty of the nation-state. In particular, this section briefly discusses the effects of globalization on the nation-state; while highlighting the nation-state's increasing authority in the area of migration or population movements. In short, this section concludes that while the postmodern critiques of the impact of economic globalization are accurate about capital movement across borders of the nation-state, it is equally important to point out that the nation-state has re-asserted itself in the face of human 
migration; hence, the rise of preventive immigration and refugee policies across Western nations. Especially, in Canada, as mention above, during the 1990s such immigration and refugee policy was introduced and used against thousands of Convention refugees, the majority of whom were of Somali origin.

In exploring the factors behind this shift in policy, this thesis notes the deep connections between Canadian immigration history and racism; and observes that while in contemporary Canadian immigration policies there are no explicit forms of discrimination, as there were at the turn of the twentieth century, there are nonetheless systemic discriminatory practices and biases that are often reflected in attitudes towards racialized minorities. The findings of this study are very much in line with the existence of a phenomenon that is often referred to as democratic racism.

More specifically, this study looks into several key areas regarding the shift in Canadian refugee policy. It reviews the evolution of Canada's refugee determination system, which is traced back to the 1978 Immigration Act and in doing so, the thesis highlights some of the differences between in land and oversea refugee claim processing methods employed by the Canadian Government; and what often compels refugees to try and make it to Canada instead of waiting in refugee camps for decades at a time for the Canadian Government to select them, if at all chosen, for resettlement in Canada. Further, this discussion touches on some of the reasons that oblige refugees to travel without identity documents or use false papers for various reasons, which include (but are not limited to): (1) refugees often need to hide their real identity from their persecutors; (2) yet others are often have to choose not to request identity documents from regimes that persecute them for fear of retaliation against family members they left behind in their in countries of origin; (2) some refugees come from countries without functioning 
governments, which means that they are unable to obtain documentation from their countries of origin - hence, many genuine refugees resort to travel with out proper identity documents, as in the case of the undocumented Somali refugees in Canada.

As discussed in previous chapters one of the main foci of this thesis is on the analysis of the Canadian Government's rationale behind the changes in refugee policy in the 1990s. In particular, the Politics surrounding the creation of section 46.04(8) of Canada's old Immigration Act e.g. the political processes and possible motives behind these processes; the Canadian Government's economic and security arguments against the undocumented Somali refugees as well as the federal government's claims about cultural incompatibility if certain Somali refugees with Canadian ways of living .e.g. the claim that "Somalis are not a group that could adapt to Canadian ways of living." The findings of this study contradict all of the arguments that were put forth by the Canadian Government. In fact, the findings in this thesis reveal that Canada imposed the identity document requirement on refugees on the basis of race and then tried to disguise this by putting forth arguments of national security, Canada's rights as a sovereign state, and social welfare security.

The other main focal point of this thesis is on the disadvantages faced by undocumented refugees as a direct result of identity document legislation and how the affected individuals respond to this legislation. In general, the Somali community in Canada has struggled against the injustices created by the identity requirement legislation for almost a decade. In particular, this initially highly fragmented community had marvelously mobilized itself political against this legislation and when the political channels did not yield any relief from the systemic discriminations that were used against them in the form of immigration and refugee policy reforms, this community utilized Canada's Charter of Rights and Freedoms and took its fight to 
the Federal Court of Canada, where the individuals affected by this legislation finally gained a much awaited relief from the hardships created by the identity requirement. In short, the findings of this thesis suggest that above all racism or racialization seems to be at the center of these restrictive immigration measures against Convention refugees that were already recognized by Canada's Immigration and Refugee Board. As mentioned above, this thesis also uniquely documents the organization and political as well as legal mobilization of the Somali community in the face of this adversity and its triumph over the injustices imposed by the identity document requirement.

In conclusion, given that the Canadian Government's restrictive refugee policy has been failing refugees both in and outside of Canada in many different ways for the past three decades because of its tendencies to be exclusive and narrow; and given that Canada has certain obligations under international law to uphold refugee rights, it is important for the nation to develop policies that go beyond the recent border control. As well, Canada as a liberal democratic nation must extend itself to contribute towards tangible humanitarian measures that address the real causes of refugee migration. Indeed, this requires a fundamental shift in both policy outlook and implementation on the part of the Canadian State i.e. more than ever before, there is a need to address the fact that most international migration today is an act of desperation not choice; contrary to popular believes in the "developed world", the vast majority of refugees prefer to repatriate to their home countries and are willing to stay there if their countries of origin are safe enough for them to live in. ${ }^{296}$

Secondly, it is imperative to emphasize the need for the development of compassionate policies towards refugees and asylum seekers everywhere in general, and in particular those who

296 Charles Keely \& Mary Kritz "Introduction" in Global Trends of Migration: Theory and Research on International Population Movement Edited by Charles Keely, Mary Kritz \& Silvano Tomasi page xiii 
seek protection at door steps of developed and industrialized nations, such as Canada, that are not only more than capable for providing for these groups, but also obligated under The 1951 Geneva Convention Relating to the Status of Refugees. Among other things, this means that the so-called "core immigration countries", such as Canada, that are receiving refugees need to reexamine the pre-refugee/pre-migration circumstances of the sending countries. ${ }^{297}$ Additionally, the Canadian Government in migration policy making must continuously engage in raising public awareness and combating racism and xenophobia, which are endemic problems that can be overcome through educating public opinion. ${ }^{298}$ This would assist in mobilizing political initiatives that could accommodate in preventing the violations of refugee rights.

Yet another crucial point that must be discussed is that the need to develop policies and systems for effective integration of refugees into the Canadian society at large, which means that there is a need to ensure policies that contribute to the creation of an economic under class that mostly consists of refugees in this country must be prevented. In other words, Canada must focus on successfully integrating refugee populations within their borders, and the most important measure of this successful immigrant/refugee integration is inter-generational economic progress in refugee communities, which was blocked by the introduction of the identity document requirement. In Canada, as the findings of this study show, such progress has important socioeconomic dimensions as refugees kept in legal-limbo for almost a decade become disproportionately dependent on the social-welfare programs of this nation, whose aging native populations will draw heavily on publicly funded social-welfare programs as well.

Lastly, while it beyond the scope of this thesis, it is rather imperative to point to the need for Foreign policies and international priorities that emphasize broad based improvements in

297 Keely \& Kritz (xv pp) 298 Simmons (1998, 94-9pp) 
human rights conditions across the world, i.e. a large number of people in this world do not have the most fundamental and basic protections of their rights in their societies - hence, the massive refugee movement of the twentieth century. Further, population stabilization and sustained development must be aggressively pursued in both "developing and underdeveloped" countries. This means that development policies that provide a significant measure of economic and political stability for these countries may be one of the ways that the international community can deal with the challenges presented by today's ever growing refugee problem of the world. 
Bibliography:-

Abu-Laban, Yasmeen

Abu Laban, Y. \& Gabriel, C.

Bhabha, Jacqueline

Basok, Tanya

Brettell, Caroline \& Hollifield, J

Brouwer, Andrew

Cairns, Alan C.

Canadian Council for Refugees

Citizenship \&Immigration Canada

Coates, Tim \& Hayward, Caitlin

Evans, Tony

Goodwin-Gill,G \& Kumin, J
"Restructuring an inclusive Citizenship for new Millennium: Globalization, Migration and Difference" in International Politics (2000) Vol. $37509-511 \mathrm{pp}$

Selling Diversity: Immigration, Multiculturalism, Employment equity \& Globalization (2000)

"Refugees, Individual Rights and State Sovereignty" Embodied Rights: Gender Persecution, State Sovereignty, and Refugees

"Refugee Policy: Globalization, Radical Challenge, or State Control" in Studies in Political Economy Vol. 50 (Summer 1996) $137-8 \mathrm{pp}$

Migration Theory Eds. (New York: Rout ledge, 2000)

What's In A Name?: Identity Documents and Convention Refugees (Ottawa: Caledon Institute of Social Policy, March 1999.) 1-20 pp

"The Living Canadian Constitutions," Canadian Federalism: Myth or Reality $2^{\text {nd }}$ Edition (Ottawa: Methuen Publication, 1971) p. 143-150.

http://www.web.net/\%7Eccr/id.htm

http://www.cic.gc.ca/english/refugees/asylum-1.html

"The Cost of Legal Limbo for Refugees in Canada" 2004 in Canada's Periodical on Refugees Vol. 22 Issue 2

"Citizenship and Human Rights in the Age of Globalization" Alternatives Vol. 25 summer 2000 423-438

Refugees in Limbo and Canada's International Obligations Caledon Institute of Social Policy. (Ottawa: September 2000) $17-20 \mathrm{pp}$ 
Hollifield, James

House of Commons

Islam, Nassir

Jakubowski, Lisa

Keely, C. \& Kritz, M.

Kelly, N. \& Trebilock, M

Kitts, H. \& Mohamed, H

Knowles, Valarie

Kubat, Daniel
"Politics of International Migration: How can we Bring the State Back in" in Caroline Brettell and James Hollifield Migration Theory Eds. (New York: Rout ledge, 2000) $137 \mathrm{pp}$

"Evidence" Minutes of meeting 33 of the Standing Committee on Citizenship and Immigration (November, 1996)

"Evidence" Minutes of meeting \# 32 of the Standing Committee on Citizenship and Immigration Proposed recommendation regarding the landing of undocumented Convention refugees (1996) 2-10pp

"Canada's Immigration Policy: Compassion, Economic Necessity or Lifeboat Ethics" in Katherine A. Graham's edition of How Ottawa Spends 1989-90: The Buck Stops Where? Ottawa: Carleton University Press, 1989), 208$240 \mathrm{pp}$

Immigration and the Legalization of Racism (Halifax: Fernwood, 1997) 10-225pp

"Introduction" in Global Trends of Migration: Theory and Research on International Population Movement Edited by Charles Keely, Mary Kritz \& Silvano Tomasi

The Making of the Mosaic (Toronto: UTP, 1998) 61-220pp

Protecting the Unprotected: Submission to the House of Commons Standing Committee on Citizenship and Immigration with respect to the proposed Regulations under the Immigration and Refugee Protection Act (February 14, 2002)

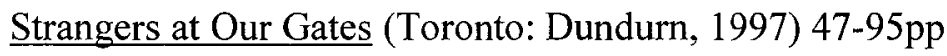

"Canada: Immigration's Humanitarian Challenge" in The Politics of Migration Policies: Settlement and Integration The first World into the 1990s Edited by Daniel Kubat (New York: Centre for Migration Studies for New York, 1993) 23-42pp 
Kumin, Judith

Lam, Lawrence

Laquian, Eleanor,

Lewis, M.I. Lewis

Matas, David \& Simon, Ilana

Mazrui, Ali

Milne, David

Olden, Anthony

Ore, Tracy E.

Patton, Mark

Pratt, A. \& Valverde, $M$
"New Approaches to Asylum: Reconciling Individual Right \& State Interests" in Refuge: Canada's Periodical on

Refugees Vol. 22 Issue No. 1 (May 2004) 3pp

From Being Uprooted to Surviving: Resettlement of Vietnamese-Chinese "Boat-People" in Montreal, 19801990 (Toronto: York Lanes Press, c1996)

"Introduction" The Silent Debate: Asian Immigration and Racism in Canada / edited by Eleanor Laquian, Aprodicio Laquian \& Terry McGee. (Vancouver: Institute of Asian Research, University of British Columbia 1998) 20-40pp

A Pastoral Democracy 1961, 1-3pp

Closing the Doors: the Failure of Refugee Protection Summer hill Press (Toronto: 1989) 87-103pp

"From Tyranny to Anarchy" in Mending Rips in the Sky the Red Sea Press, Inc. 1997 5-7pp

The Canadian Constitution (Toronto: J. Lorimer, 1991) 235-250, 280-290 pp

"Somali Refugees in London: Oral Culture in a Western Information Environment" in Libri (1999, vol. 49, pp. 212 214.) Centre for Information Management, Thames Valley University, London, UK. Printed in Germany

The Social Construction of Difference \& Inequality: Race. Class, Gender and Sexuality (2002)

An Exploration of the Limits of Culture and the Integration of Experiences of Somali Newcomers in Ottawa. (1996, 13pp)

"From Deserving Victims to 'Masters of Confusion': redefining refugees in the 1990s" in Canadian Journal of Sociology Vol. 27 Issue No. 2 (2002) 148-151pp 
Razack, Sherene

Richmond, Anthony

Samatar, Ahmed

Satzewich, Vic

Sens, Allen \& Stoett, Peter

Simmons, Allan

Stasiulis, D \& Bakan, A

Tie, Chantal

Torpey, Jonathan

Vickers, Jill \& Dhruvarajan, V.
"Simple Logic: Race, the Identity Document Rule, and the Story of a Nation Besieged and Betrayed" in Journal of Law and Social Policy Vol. 15 (2000) 183-200pp

"Making Canada White: Law and the Policing of Bodies of Colour in the 1990s" in Canadian Journal of Law and

Society, 14(1), (Spring 1999)159-184pp

"Refugees and Racism in Canada" in Refuge: Canada's Periodical on Refugees Vol. 19 Issue No. 6 (August 2001) $15 \mathrm{pp}$

Global Apartheid: Refugees, Racism and the New World Order (Toronto: 1994) 130-170pp

Somalia: State Collapse, Multilateral Intervention, and Strategies for Political Reconstruction Washington, D.C.: Brookings Institution, c1995. 14-20pp

Racism \& Social Inequality in Canada Thompson Education Publishing (Toronto: 1998) 1-60pp

Global Politics: Origins, Currents, Directions Australia; Scarborough, ON: Nelson Thomson Learning, 2002. 34pp

"Racism and Immigration Policy" in Racism and Social Inequality in Canada (Toronto: 1998) 87-100pp

Negotiating Citizenship: Migrant Women in Canada and the Global System (2003) 1-20pp

"Section 46.04(8) Identity Document Constitutional Challenge Settled on Consent in Federal Court - Trail Division" in Immigration Law Reporter $3^{\text {rd }} \mathrm{Ed} .2000$ 202215pp

"Coming and Going: On the State Monopolization of the Legitimate Means of Movement" in Sociological Theory November 1998, vol. 16, no. 3, pp. 239-259(21)

Gender, Race, and Nation: a Global Perspective Toronto University Press) (2002) 
Whitaker, Reg

Winks, Robin

Young, Marta
"Refugees: The Security Dimension" in Citizenship Studies Vol. 2 (3) 413-4pp

The Blacks in Canada: A History McGill-Queen's Press (Montreal: 1971) 435pp

"Expert Report of Dr. Marta Young". 


\section{Appendix A:}

\section{Letter of Information and/or Phone Contact Script}

You are being asked to provide some information for a research study conducted by Rahma Abdulkadir, who is a graduate student enrolled in a Master of Art degree program at Carleton University. The project is being supervised by Dr. Daiva Stasiulis of the Department of Sociology and Anthropology at Carleton University.

This research project is a study of Canada's identity document requirement from recognized Convention refugees within its borders which was introduced in 1993 as an amendment to Canada's Immigration Act and stipulated "an immigration officer shall not grant landing... unless the applicant is in possession of a valid and subsiding passport or travel document..."299, as well as its implication for the equality rights of recognized Somali Convention refugees in Canada. The purpose of this thesis is to evaluate the implications and the rational behind the identity document requirement, as a result of which Canada's federal immigration department denied permanent residence status to recognized Convention refugees in Canada, the majority of whom were of Somali origin, because they were not able to provide "satisfactory" identity documents required under this provision of the Immigration Act. Thus it is the aim of this thesis to question whether Canada's identity document requirement discriminated against Somali recognized Convention refugees in Canada by denying them equality rights.

The findings of this research will be presented in the researcher's Master of Arts Thesis that will be submitted to Carleton University's School of Graduate Studies and Research in partial fulfillment of the requirement for Master of Arts degree.

\footnotetext{
${ }^{299}$ Guy S Goodwin-Gill \& Judith Kumin Refugees in Limbo and Canada's International Obligations Caledon Institute of Social Policy (Ottawa: September 2000) 17pp
} 
The procedure for gathering information will include either: an open-ended questionnaire or interview - whichever is most convenient for you. The interview/questionnaire may take up to an hour to complete, and participants may decline to answer any question. The questions will focus on Canada's identity document requirement from recognized Convention refugees and its implication for the equality rights of recognized these refugees in Canada. Please verify your permission to participate in this study with the administrators of your agency, if applicable.

You may withdraw your agreement to participate at any time during the interview/questionnaire, or for up to 7 days after completion of the interview/questionnaire. At that time, you may indicate whether or not the data collected up to that point can be used in the study, and any information you do not give permission to use will be destroyed immediately. After 7 days, the researchers may begin to use your ideas to shape further research and as such, cannot 'un-do' the use of certain responses. There is a possibility that researchers may contact you for further clarification of your responses for a period of up to three months after the completion of the interview/questionnaire.

The researcher is willing to correspond with you at a time that is convenient for you either by telephone, email, fax, mail, or in-person (where geographically possible). Please note that the researcher cannot ensure the security of information that is transmitted via email or fax. Interviews will not be taped, and the researchers will not use personal or organizational names or identifying information in any public reports or presentations. However, because of the potentially small number of participants, the descriptive nature of the information being requested, and the potential for insecure data transmission, the researcher cannot ensure the content of the report will not be traceable to the research participants. As such, you are 
encouraged not to share any information that you do not wish to be associated with you or your agency.

There are very few known risks associated with participation in this study. However, because the researcher cannot ensure complete anonymity, potential risks may include negative reactions from unknown others if they feel threatened by or opposed to report findings that they (correctly or incorrectly) attribute to you. Participant responses will be stored indefinitely in a locked filing cabinet to which only the researcher will have access. During the data collection phase of the project, information received by e-mail will immediately be printed, and the message deleted. As mentioned above, after the project is completed and a summary report of the data is compiled, the researcher will continue to store the data in locked filing cabinet for future research purposes, such as classroom lectures, conference presentations and journal articles.

This project has been reviewed and received ethics approval from the Carleton University Research Ethics Committee. Those participants with concerns or questions about their involvement in the study may contact:

Prof. Antonio Gualtieri, Chair

The Carleton University Research Ethics Committee

Office of Research Services

511A Tory Building, 1125 Colonel By Drive

Ottawa, ON K1S 5B6

Tel: (613) 520-2517

E-mail: ethics@carleton.ca

Questions and concerns may also be directed to any of the following individuals:

Professor Daiva Stasiulis, Research Study Supervisor

613-520-2600 ext. 1098

dstasi@,ccs.carleton.ca 
Rahma Abdulkadir, Student Researcher

E-mail: rabdulk2@,connect.carleton.ca

Thank you for your interest,

Sincerely,

Rahma Abdulkadir (Student) 


\section{Appendix B:}

\section{Informed Consent Form}

I understand that I am being invited to participate in a research study conducted Rahma Abdulkadir, who is a graduate student enrolled in the Masters of Art degree program at Carleton University. I have read the letter of information that has been provided by the researcher, and I understand that the information I provide will be used to complete a project that will be presented in the form of a chapter in the researcher's Master of Arts Thesis that will be submitted to Carleton University's School of Graduate Studies and Research in partial fulfillment of the requirement for Master of Arts degree.

I understand that the purpose of this paper is to evaluate Canada's identity document requirement from Convention refugees within its borders and the implications of this legislation that dictated the government of Canada denied permanent residence status to recognized Convention refugees in Canada, majority of who were of Somali origin because they were not able to provide "satisfactory" identity documents required under this provision of the Immigration Act that was introduced in 1993.

I understand that I may choose to provide information through either: an open-ended questionnaire or an open-ended interview where I will be asked to share my knowledge and experience about evaluate Canada's identity document requirement. I realize that the interview/questionnaire may take up to an hour to complete, and that I may decline to answer any question. I understand that I am being asked to verify my permission to participate in this study with the administrator of the agency I represent, if this is applicable. I understand that I may withdraw agreement to participate at any time during the interview/questionnaire, or for up to 7 days after completion of the interview/questionnaire. At that time, I know that I may indicate whether or not the data collected up to that point can be used for the study, and that any 
information I do not want used will be destroyed immediately. After 7 days, I realize that the researcher may begin to use my responses to direct further research. I understand there is a possibility that reséarcher may contact me for further clarification of my responses for a period of up to three months after the completion of my interview/questionnaire.

I understand that I have the choice of responding to the interview or questionnaire via email, telephone, fax, mail, or in person (if feasible). I understand that the researcher cannot ensure that my participation will be completely anonymous, and that there is increased risk to anonymity if I respond via email or fax, or choose to be interviewed in a public place or at my workplace. I understand that the researchers will not include identifying information in any report, summary, or presentation that is made available to others, but there remains some risk that others will be able to link my responses to me or my agency. As such, I understand that I am under no obligation to share any information that I do not wish to be associated with my agency or me. I understand there is a risk that I may experience negative reactions from others who do not agree with the study findings. As well, I realize that this study may not directly benefit my agency or me because it may be possible for others to connect my responses to me or to my agency.

I understand that only the researcher will see the data collected, and that my response will be stored indefinitely in a locked filing cabinet to which only the researcher will have access. Also, I understand that after the project is completed and a summary report of the data is compiled, the researcher will continue to store the data in locked filing cabinet for future research purposes, such as classroom lectures, conference presentations and journal articles. 
I understand that the findings of this study will be presented in the form of a chapter in the researcher's Master of Arts Thesis that will be submitted to Carleton University's School of Graduate Studies and Research in partial fulfillment of the requirement for Master of Arts degree. I realize that the presentation may be published on the World Wide Web for a period of up to five years. I understand that a copy of the report may be obtained by members of the public (that is, there is no need to identify as a 'participant') by contacting Carleton University library

I understand that this project has been reviewed and received ethics approval from the Carleton University Research Ethics Committee. Those participants with concerns or questions about their involvement in the study may contact:

Prof. Antonio Gualtieri, Chair

The Carleton University Research Ethics Committee

Office of Research Services

511 A Tory Building 1125 Colonel By Drive

Ottawa, ON K1S 5B6

Tel: (613) 520-2517

E-mail: ethics(a)carleton.ca

Questions and concerns may also be directed to any of the following individuals:

Professor Daiva Stasiulis, Research Study Supervisor

613-520-2600 ext. 1098

dstasi@,ccs.carleton.ca

Rahma Abdulkadir, Student Researcher

E-mail: rabdulk2@,connect.carleton.ca

Name of Participant:

Signature of Participant:

Or, 'Do you agree to participate in the study I have just described?'

Yes

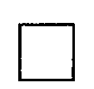

No

Signature of Researcher:

Date:

Time: 


\section{Appendix C:}

\section{Interview/Questionnaire Guide}

Name of Participant:

Agency Name (if applicable):

Contact Information:

Informed Consent:

(Attach copy)

Form Signed $\square \quad$ Verbal Agreement

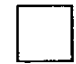

1. Are you familiar with the Canada's identity document requirement from Convention refugees?

2. Do you have a clear understanding of this legislation and why it was introduced?

3. In your opinion, why did the Government of Canada introduce this legislation? More specifically, what do you think was the rationale/logic behind this legislation?

4. Do you believe that this legislation has fulfilled its own policy objectives

5. Do you know personally or professionally convention refugees who were/are affected by this legislation?

6. In your opinion, were/are there any specific ethnic or national groups that were almost exclusively affected by this legislation? Do you believe that there were strong adverse impacts on this group?

7. In your opinion, why was this group of people the target of this legislation?

8. In your opinion, how did Canada's identity document requirement discriminate against this group of Convention refugees in Canada? 


\section{Appendix D:}

\section{List of Interviewees}

Interview \#1 Citizenship \& Immigration Canada Official

Interview \#2 Immigration \& Refugee Lawyer

Interview \#3 Immigration \& Refugee Lawyer

Interview \#4 Immigration \& Refugee Lawyer

Interview \#5 Immigration Canada Official

Interview \#6 Refugee Case Worker

Interview \#7 A Director of a Community Organization

Interview \#8 Refugee Serving Agency Manager

Interview \#9 Immigration \& Refugee Lawyer

Interview \#10 Refugee Case Worker

Interview \#11 Community Legal Worker 